\title{
Does Direct Democracy Reduce the Size of Government? New Evidence from Historical Data, 1890-2000
}

\author{
Patricia Funk \\ Universitat Pompeu Fabra \\ Christina Gathmann \\ Stanford University
}

First Draft: December 2007

This Draft: October 2008

\begin{abstract}
Using historical data for all Swiss cantons from 1890 to 2000, we estimate the causal effect of direct democracy on government spending. The main innovation in this paper is that we use fixed effects to control for unobserved heterogeneity and instrumental variables to address the potential endogeneity of institutions. We find that the budget referendum and lower costs to launch a voter initiative are effective tools in reducing canton level spending. However, we find no evidence that the budget referendum results in more decentralized government or a larger local government. Our instrumental variable estimates suggest that a mandatory budget referendum reduces the size of canton spending between 13 and 19 percent. A 1 percent lower signature requirement for the initiative reduces canton spending by up to 2 percent.
\end{abstract}

*Correspondence: Patricia Funk, Department of Economics, Universitat Pompeu Fabra, Email: Patricia.Funk@upf.edu; Christina Gathmann, CHP/PCOR, Stanford University, Email: cgathman@ stanford.edu. We thank Ran Abramitzky, Betty Blecha, Paula Bustos, Antonio Ciccone, Sudip Chattopadhyay, Raquel Fernandez, Humberto Llavador, Grant Miller, Per Pettersson-Lidbom and participants at the EEA Meetings, CERGE-EI, Central European University, Pompeu Fabra, San Francisco State University and University of Queensland for useful comments and discussions. We are grateful to Magdalena Schneider and Elisabeth Willen from the Swiss Bureau of Statistics, Andreas Ladner, Christian Bolliger, Alexander Trechsel and employees of canton archives for answering our questions on the data. Christina Gathmann thanks the Hoover institution for its hospitality and financial support. Patricia Funk gratefully acknowledges financial support from the Ramon y Cajal research grant. 


\section{Introduction}

Recent decades have seen a surge of research on the economic effects of institutions. A large body of literature has emerged that demonstrates how constitutional rules like the electoral system or the form of government fundamentally shape policy choices.

In democracies, a particularly important institutional choice is between representative and direct forms of government. Past centuries witnessed the gradual replacement of direct democracy, where all political decisions were made by its citizens, by more representative forms of government. More recently however, direct democracy has experienced a remarkable renaissance both in practice and the political debate. The number of ballot initiatives, which allow citizens to propose new laws, has surged in the United States over the past decades, the most famous case being Proposition 13 in California. The introduction of referendums, where citizens have to approve policies chosen by the government, has in turn been on the agenda of such diverse political bodies as the European Union and several republics in the former Soviet Union.

The rising public and political interest in direct democracy is fueled in part by the belief that direct voter control could slow down or even reverse the rapid growth in government spending observed in many countries over the past decades. To evaluate the merit of these beliefs and policy proposals favoring direct participation however requires first a thorough understanding of the link between direct democracy and fiscal policy choices. In this paper, we examine how direct democracy affects fiscal policy within a representative democracy. In particular, we analyze and compare empirically the effect the two most popular direct democratic institutions, the referendum and the voter initiative, on government spending.

Theoretically, the basic tradeoff in a representative democracy is between the preferences of voters (principal) and the incentives of their elected representatives (agent). A widely held belief 
is that career concerns by politicians, asymmetric information or imperfect electoral competition encourage politicians to pursue larger governments than desired by the median voter. In this scenario, theory suggests two channels why direct democracy will bring actual policies closer in line with the preferences of the median voter. The first channel is that referendums (Romer and Rosenthal 1979) or initiatives (Gerber, 1996; Moser 2000) can be used as a threat point by voters to impose spending discipline on elected representatives. The impact of the referendum or initiative on government spending is thereby independent of whether the initiative or referendum is actually used in practice or not.

A second argument is that referendums or initiatives allow citizens to select their preferred choice for specific policies. In contrast, parliamentary or presidential elections require citizens to elect a candidate, each of them representing a whole bundle of policy proposals. Consequently, the choices of the legislature on any single issue might be very different from the actual preferences of the median voter (e.g. Buchanan and Tullock, 1962; Besley and Coate, 2002). In contrast to the first mechanism, the effectiveness here depends on the actual usage of the institutions. Both channels imply that access to direct democratic institutions should decrease the size of government if voters are more fiscally conservative than politicians (e.g. Peltzman, 1992).

While a number of studies have analyzed the relationship between direct democracy and fiscal policy empirically, ${ }^{1}$ it is difficult to interpret the existing results as causal effects of direct democracy on government policy (see Pettersson-Lidbom and Tyrefors, 2007). Like other political institutions that are written into a country's constitution, direct democracy is very persistent over time. Though some studies use panel data, their estimates are predominantly identified by cross-sectional variation and hence, cannot include fixed effects. However, if there

\footnotetext{
${ }^{1}$ Bails and Tieslau (2000), Besley and Case (2003), Farnham (1989), Matsusaka (1995; 2000; 2004) and Zax (1989) for the United States; Feld and Matsusaka (2003), Funk and Gathmann (2008) and Pommerehne (1978) for Switzerland.
} 
are unobserved state-specific factors that are correlated with both spending and direct democracy, these estimates will suffer from omitted variable bias. Another issue is that institutions might be themselves determined by past fiscal policy choices. For example, it is reasonable to assume that citizens would demand stricter control over government budgets after a long period of overspending.

To identify the causal effect of direct democracy on government, we hand-collected a new dataset on all Swiss cantons between 1890 and 2000. We gathered the provisions for direct democratic control by carefully going through each canton's past and present constitutions and all relevant state laws. We combined this institutional information with detailed data on public finances and socio-demographic characteristics for all cantons since the late 19th century. A unique advantage of our long time period is that we observe substantial variation in the direct democratic institutions over time. We can therefore estimate fixed effect models to control for all permanent differences across cantons.

We address the potential endogeneity of the direct democratic institutions using instrumental variables. In Switzerland, changes in direct democratic institutions always require a revision of the constitution. Hence, a candidate for an instrument is how difficult it is to change the canton constitution. We provide several historical examples to illustrate that the constitutional initiative, which allow citizen to request a revision of the constitution, has frequently been used to implement changes in direct democratic institutions since the nineteenth century. We also present anecdotal and more formal evidence suggesting that the constitutional initiative is plausibly exogenous from the spending regression. Consequently, we use the provisions of the constitutional initiative in each canton since the late 19th century to identify the causal effect of direct democracy on government spending.

Given its long direct democratic tradition, Switzerland provides a unique setting for our 
analysis. The cantons differ widely in their provisions for direct democratic participation. These institutional differences allow us to separate the effects of the referendum to those of the voter initiative. Budget referendums require that investment projects have to be approved by the voters if their costs exceed a certain threshold. The voter initiative allows the voters to propose entirely new laws. Since all cantons in Switzerland allow for the voter initiative over most of our sample period, we exploit differences in the signatures required to launch an initiative.

While budget referendums have a direct influence on spending policies, citizens have little leverage about the type of projects voted upon. ${ }^{2}$ In contrast to the referendum, citizens can use the voter initiative to directly set the agenda how to restrict the government. However, getting an initiative on the ballot requires additional effort of preparing an initiative and collecting the necessary signatures. Voter initiatives thus impose overall higher cost on citizens than a referendum mandated by law. Hence, it is a-priori an open question which of the two institutions is effective in constraining the size of government.

Our results provide strong evidence that it is important to account for unobserved heterogeneity. While the effects of the budget referendum and voter initiative we identify are negative, they are much smaller than those typically reported in the previous literature. Our fixed effect estimates show that the mandatory budget referendum is associated with 3.4 percent lower expenditures at the state level. Increasing the signature requirement, measured in percent of the eligible population, by one standard deviation raises canton expenditures by 2.4 percent. ${ }^{3}$ These estimates are quite robust to adding more controls or using different specifications. For

\footnotetext{
${ }^{2}$ The budget referendum we analyze here is most closely related to budget or project-based referendums of local school districts in the United States. An institution related to a referendum on tax increases are legal tax and expenditure limitations, commonly found in the United States (see Bohn and Inman, 1996; Poterba, 1994; Rueben, 1997; Von Hagen, 1991).

${ }^{3}$ For example, Feld and Matsusaka (2003) report the equivalent of 20 percent lower expenditures for the budget referendum in Swiss cantons. The results on the voter initiative are close to the 4 percent reported in Matsusaka (1995) for the United States.
} 
example, we show that shifts in the demand for government over our 110 years period do not affect our basic results. We also find that our results are robust to alternative specifications of our direct democracy variables and changes in voting rights or the electoral system.

Next to analyzing the effect of direct democratic institutions on canton spending, we investigate whether the budget referendum and voter initiative decentralize spending to lower levels of government. In contrast to previous studies (Feld et al, 2008; Matsusaka, 1995), we demonstrate that the budget referendum does neither increase local spending nor decentralize spending once we account for permanent differences across states.

However, we find that high spending periods are one motivation to adopt stricter budget controls. To account for this institutional endogeneity, we use the provisions for changing the canton constitution as an instrument. The instrumental variable estimates show that the budget referendum decreases state governments by 13 to 19 percent while there is again no effect on local spending. In addition, a one standard deviation lower signature requirement for the initiative decreases canton spending between 6 and 9 percent, but has no effect on local governments.

The paper makes several contributions to the literature. First, we are able to control for unobserved heterogeneity and the potential endogeneity of direct democratic institutions. The approach used in this paper is close in spirit to Poterba (1996) and Besley and Case (2000; 2003) who emphasize the importance of identifying the causal effects of political institutions. ${ }^{4}$

Second, we use changes in constitutional rules as instruments to identify the causal effect of direct democracy on the size of government. Our analysis hence contributes to a small, but growing literature that addresses the endogeneity of political institutions at the sub-national

\footnotetext{
${ }^{4}$ Petterson-Lidbom and Tyrefors (2007) also focus on identification by using a regression-discontinuity design. However, their analysis is not about direct democratic institutions in a representative democracy. Rather, they compare Swedish communities between 1930-1950, that were either entirely run by town meetings or by representative forms of government. Their results indicate that direct democratic communities spent 10-13 percent less.
} 
level using an instrumental variable approach (Feld and Matsusaka, 2003; Knight, 2000; Rueben, 1997). ${ }^{5}$ The advantage of our historical data is that we have enough time variation in the institutions to account for both unobserved heterogeneity across cantons and the potential endogeneity of institutions. In contrast, previous studies could not implement an instrumental variable approach within a fixed effects framework.

Since we separate the effect of the initiative from those of referendums, our findings also 'unbundle' the causal effect of specific institutional rules (see Acemoglu and Johnson, 2005; Feld and Matsusaka, 2003). Separating the causal effects of direct democratic institutions is important for both theory-building and public policy. It is only if we know which particular institutional rule actually affects policy outcomes that policy recommendations can be made.

The paper is organized as follows. In the next section, we provide background information on direct democracy in Swiss cantons. We describe our new historical data set in section 3 . The fixed effect estimates and various robustness tests are reported in section 4 . In section 5 , we use instrumental variables to identify the causal effect of the referendum and initiative on the size of government. Section 6 concludes.

\section{Direct Democracy and Fiscal Policy in Switzerland}

Switzerland has a strong federalism where cantons bear all political responsibilities unless they were granted to the federal government in a national referendum. In 1998, 34 percent of all government spending was undertaken by cantons, 39 percent by the federal and 27 percent by local governments. Cantons have a lot of autonomy both in the provision of public goods and services as well as the redistribution of wealth. The distribution of revenues across government

\footnotetext{
${ }^{5}$ There is however a large literature using instrumental variables for institutions in a cross-country setting. See for example, Acemoglu, Johnson and Robinson (2001); Hall and Jones (1999); Persson and Tabellini (2003; 2004).
} 
levels is equally decentralized. The tax burden (mean=100) varied from 58.2 in $Z u g$ to 126.7 in Neuchatel in 2000.

Direct democracy has always played a dominant role in Swiss politics (see Curti, 1900; Trechsel and Serdült, 1999; Vatter 2002). At the federal level, the referendum and voter initiative (Begehren) to demand a total revision of the constitution have been in place since the Confederation was founded in 1848 (Kölz, 1992). In cantons like Appenzell, Glarus or Uri, direct voter participation goes back to the thirteenth and fourteenth centuries, when the electorate decided on all political affairs in town meetings. By 1850, the voter initiative to propose new laws was in place in Glarus, Vaud and Nidwalden.

The two most popular -and most fiscal policy relevant- direct democratic institutions in the 25 Swiss cantons and elsewhere are the budget referendum and the voter initiative. ${ }^{6}$ The budget referendum allows citizens to approve or decline individual projects proposed by the canton government involving large one-time or recurring expenditures. While budget referendums can be about expenditures, public sector bonds, taxes, enterprise holdings and real estate, we restrict attention to referendums on public expenditures, which are by far the most common.

Today, most cantons have some form of budget referendum in place. In 2000, fifteen cantons had a mandatory budget referendum, which requires citizens to vote on a project that exceeds a certain threshold. ${ }^{7}$ Ten cantons allow only for an optional budget referendum where citizens need to collect between 100 and 10,000 signatures to vote on a project above the threshold. The canton of Vaud does not provide for any type of budget referendum.

Between 1980 and 1999 alone, citizens in the 25 cantons voted on 461 budget referendums and approved 86 percent of the projects (Trechsel and Serdült, 1999). Control over the budget

\footnotetext{
${ }^{6}$ The canton Jura was founded in 1978 and is excluded from our analysis.

${ }^{7}$ Thresholds for non-recurring expenditures range between 25 Million Swiss Francs (SFr) in Lucerne and 250,000 SFr in Schwyz (1999). This implies that a project of on average 6.8 million SFr or just less than 1 percent of average expenditures mandates a referendum. For recurring expenditures, thresholds range between 50,000 (Appenzell-Innerrhode, Basle County, Nidwalden, Ticino and Uri) and 400,000 SFr (Berne).
} 
is stronger in cantons with mandatory budget referendum, since voter approval is mandated by law. If voters are fiscally more conservative than politicians, we expect that a mandatory budget referendum decreases government spending. ${ }^{8}$

The second direct democratic institution is the voter initiative, which allows citizens to propose entirely new laws. Their success rates range from 0 percent in Schwyz or Fribourg to 50 percent in Vaud or Basle City. Today, the voter initiative is available in all cantons. In most cases, the voter initiative was adopted several decades prior to the beginning of our sample period in 1890. There is however substantial variation in the number of signatures for getting an initiative on the ballot: in 2000, the numbers ranged from 1 in Glarus and AppenzellInnerrhode to 12,000 in Vaud. Voters can more easily influence political decisions when costs to launch an initiative are low. If voters are more fiscally conservative than politicians, higher signature requirements imply that voter control is more costly, which in turn might increase government spending.

The two institutions differ in how much leverage citizens have over the budget and the costs for the voter. Under the budget referendum, citizens are restricted to approve or dismiss individual spending projects. With the voter initiative, citizens have also other means to influence the budget, e.g. by proposing expenditure limitations. However, this flexibility comes at a cost: launching an initiative is more costly to the voter than a referendum mandated by law. Hence, it is an open empirical question which instrument is more effective in constraining the size of government.

Table 1 provides an overview of the direct democratic institutions in each canton in 2000 . Column (1) shows the canton that have a mandatory budget referendum in place and column

\footnotetext{
${ }^{8}$ Several cantons allow for both a mandatory and optional budget referendum: Zurich, Lucerne, Uri, Obwalden, Nidwalden, Fribourg, Solothurn, Schaffhouse, Appenzell-Innerrhode, St. Gallen, Grisons, and Thurgau. A comparison between cantons with mandatory and optional budget referendum to cantons with an optional or no budget referendum will therefore provide a lower bound of the full effect of a mandatory budget referendum relative to no referendum (see Feld and Matsusaka, 2003).
} 
(3) lists the total number of signatures required to launch a voter initiative. Reading across columns shows that the two direct democratic institutions are positively correlated. Cantons with a mandatory budget referendum are also more likely to have a lower signature requirement (correlation coefficient: -0.18$)$.

Overall, direct democracy is stronger in the German-speaking parts, which include both the large urban centers of Basle, Zurich or Berne but also the interior of Switzerland. Figure 1 shows the geographic location and strength of direct democratic institutions in Swiss cantons. Direct democratic traditions are weaker in the dominantly French- and Italian-speaking cantons located in the southern and western parts of the country.

While deep political institutions (like direct democracy) are typically very persistent over time, columns (2) and (4) in table 1 show substantial variation in the provisions for the budget referendum and the signature requirement between 1890 and 2000. Specifically, twelve cantons adopt the mandatory budget referendum over our 110 years period while nine cantons abolish the mandatory budget referendum in favor of an optional one. We also observe nineteen increases in the signature requirement for the voter initiative and four decreases. In addition, six cantons adopt the voter initiative over our sample period. ${ }^{9}$ Before analyzing the effect of these changes on policy choices, we describe our data sources.

\section{Data Description}

We collected a rich new dataset on political institutions, fiscal policy and socio-economic characteristics for all twenty-five cantons in Switzerland between 1890 and 2000. Most importantly, our analysis requires comprehensive measures of direct democratic institutions in each state and year. We extracted this information from the past and current constitutions as well as

\footnotetext{
${ }^{9}$ Geneva in 1891, Ticino in 1892, Berne in 1893, Lucerne in 1906, Valais in 1907 and Fribourg in 1921.
} 
the relevant state laws in each canton between 1890 and today. We used several published sources to validate and cross-check our coding of the institutional variables (Kölz, 2004; Monnier, 1996; Ritzmann-Blickernstorfer, 1996; Trechsel and Serdült, 1999; Vatter, 2002). If in doubt, we contacted the respective cantonal Public Record Offices (Staatsarchive) to clarify any inconsistencies.

The main institutional variable of interest is a binary indicator equal to one if a canton has a mandatory budget referendum and zero if the canton has only an optional budget referendum or no budget referendum in place. Our second institutional variable characterizes the provisions for the voter initiative.

Since the voter initiative is available in all cantons for most of our sample period, we use the number of signatures required to get an initiative on the ballot. ${ }^{10}$ We measure this variable as percentage of the eligible voters, which assumes that the collection of 1,000 signatures is more costly in a canton with only 5,000 citizens than in a canton with 100,000 citizens. ${ }^{11}$ Since the number of eligible voters changes over time, we have a lot of variation in our measure of the voter initiative in addition to the observed changes in the absolute number of signatures required.

We complement this information with detailed public finance statistics and a rich set of demographic controls. These variables were collected by digitizing printed information from the 'Statistical Yearbook of Switzerland', the 'Historical Statistics of Switzerland' and the decennial Census. The data appendix provides a detailed description of the data sources and the construction of variables between 1890 and today.

\footnotetext{
${ }^{10}$ For the cantons adopting the voter initiative after 1890 , we assigned an arguably arbitrary signature requirement for the years prior to adoption. Luckily, estimates remain unchanged whether we choose $20,30,50$ or 100 percent as the signature requirement for non-adopters. The results reported in the paper use the 30 percent signature requirement.

${ }^{11}$ Alternatively, one could assume a fixed cost of collecting signatures. In that case, the absolute number of signatures for the voter initiative is the relevant statistic. We report those results in the robustness section.
} 
Table 2 shows summary statistics for all variables used in the empirical analysis. ${ }^{12}$ The table shows the mean and standard deviation separately for cantons with and without a mandatory budget referendum. The last column reports the t-statistic for the mean comparison across the two groups.

Our main outcome variables are annual per capita expenditures and revenues in each canton as well as total per capita expenditures at the local level. All expenditure and revenues variables are deflated to 2000 Swiss Francs. We also construct a centralization measure calculated as the percentage of local plus canton expenditures that is spent at the canton level. In the raw data, log canton expenditures and revenues are not statistically different between cantons with and without a mandatory budget referendum. However, cantons with a mandatory budget referendum have significantly higher local spending and less centralized expenditures.

Cantons with stronger direct democracy differ from other cantons also in their demographic, political and economic structure. They have a lower signature requirement for the voter initiative and a smaller executive. In addition, they are more likely to have a mandatory referendum for laws in place and less likely to elect their parliaments using proportional representation. Further, cantons with a mandatory budget referendum are more likely to be located in the German-speaking part of Switzerland, have a different age structure and a larger share of rural population.

One control variable that is not available in our data set is canton income (or wages). Both are only available since the 1960s. We use several variables to control for differences in wealth in our empirical analysis. Specifically, we use the labor force participation rate, the percentage of the population owning a car, the number of doctors per capita and the infant mortality rate to control for income differences. These four variables alone account for 47 percent of the variation

\footnotetext{
${ }^{12}$ Table A1 in the appendix decomposes the variation of each variable into a within canton and between canton component. Most importantly for our fixed effects approach, the table shows that there is a lot of within canton variation in government spending, a canton's political institutions and socio-demographic characteristics.
} 
in canton income since 1965, which is astonishing given that declines in infant mortality rates typically occurred much earlier in the century. Once we include our other control variables, for example the size of the agricultural and industrial sector, the age structure of the population and the share of the urban population as well as canton and year fixed effects, we can account for 93 percent of the variation in canton income. Hence, we believe that the absence of a precise measure of canton income is not a major limitation of our study. We now turn to our main results.

\section{Direct Democracy and Fiscal Policy: Fixed Effects}

\subsection{Canton Expenditures and Revenues}

Our descriptive evidence showed that cantons with stronger direct democratic institutions are very different in their observable characteristics. We might therefore expect that they also differ along other, unobservable dimensions. Surely, demographics and hence the demand for government goods and services are likely to change over the 110 years period. However, our detailed study of the historical and current constitutions also revealed institutional differences that are largely fixed over time. For instance, citizens can recall the executive or directly elect the president of the executive in some cantons but not in others. We would expect that both features constrain politicians in their policy choices. Omitting these factors would therefore bias our results upward if cantons with stronger direct democracy also permit other forms of citizen control over the government. ${ }^{13}$

A unique feature of our long panel is that we can control for all permanent differences across

\footnotetext{
${ }^{13}$ Controlling for unobserved heterogeneity seems also important since evidence suggests that fiscal policy and political institutions vary substantially between German- and French-/ Italian-speaking cantons even after controlling for a large number of canton characteristics.
} 
cantons by fixed effects. In particular, we estimate the following empirical model,

$$
\log Y_{c t}=\alpha+\beta \text { Referendum } \text { ft }_{c}+\gamma \text { Initiative }_{c t}+\lambda^{\prime} X_{c t}+t_{t}+\theta_{c}+\varepsilon_{c t}
$$

where the subscript $c$ denotes the canton and $t$ the year. $\log Y_{c t}$ is expenditures or revenues measured in logs and $X_{c t}$ denotes other control variables. Our year and canton fixed effects are represented by $t_{t}$ and $\theta_{c}$ respectively. $\varepsilon_{c t}$ is assumed to be an iid error term reflecting for example, measurement error in expenditures or revenues. The main parameters of interest are $\beta$ and $\gamma$, which capture the effect of the budget referendum and signature requirement on expenditures respectively. Based on our discussion above, we expect that $\beta<0$ and $\gamma>0$.

Table 3 shows the basic results of a regression where the dependent variable is the log of annual per capita expenditures. ${ }^{14}$ The first specification with our two direct democratic institutions and year dummies shows a strong negative correlation $(-0.267)$ between the mandatory budget referendum and government spending. A higher signature requirement for the voter initiative is negatively correlated with canton expenditures.

The second column adds our set of variables to control for observable differences across cantons. The coefficient on the budget referendum drops to 9.3 percent while the coefficient on the voter initiative flips sign. In this specification, an increase in the signature requirement by one standard deviation (or 4.7 percent) is associated with 1.9 percent higher spending.

Our preferred specification, which controls for all permanent unobservable differences with canton fixed effects, is shown in column (3). The coefficients are now identified from cantons adopting or abolishing a mandatory budget referendum and canton changes in the signature re-

\footnotetext{
${ }^{14}$ There are several reasons why we choose the log specification: first, cantonal expenditures are log normally distributed. Also, spending 1,000 Swiss Francs weighs more if the overall budget is smaller. Finally, the log specification allows a simple interpretation of the coefficient on the institutional variable. Results using the level of spending were similar and available upon request.
} 
quirement for the voter initiative. ${ }^{15}$ The fixed effects are statistically highly significant (see last row of table 3) and have a substantial impact on the coefficients of the budget referendum and voter initiative. The effect of the budget referendum declines to -3.4 percent which corresponds to a reduction of more than 60 percent relative to column (2). In contrast, the effect of the voter initiative actually becomes somewhat stronger with canton fixed effects. If the signature requirement for the voter initiative were raised by one standard deviation, expenditures would be 2.4 percent higher.

Even after controlling for unobserved heterogeneity however, the mandatory budget referendum decreases government spending. We also find that making voter initiatives more costly for the electorate induces more spending by politicians. Both results are consistent with the view that voters are fiscally more conservative than politicians.

Do we see a similar picture on the revenue side? The estimates on the right-hand side of table 3 show that, once we control for permanent differences across cantons (column (6)), we find no statistically significant differences in revenues between cantons with and without mandatory budget referendum. This result suggests that cantons with less direct democracy finance their public expenditures in part by running deficits. However, higher costs to launch a voter initiative still result in more revenues and the effect is stronger than on the expenditure side. An increase in the signature requirement by one standard deviation is associated with 2.8 percent more revenues.

The other control variables have largely the expected sign both for expenditures and revenues. For instance, cantons with lower infant mortality rate and a higher percentage of car ownership have higher spending as do cantons with more subsidies from the federal level. These

\footnotetext{
${ }^{15}$ The changes in the coefficient with canton fixed effects could also be driven by differences in spending patterns between cantons that adopt or abolish the budget referendum and cantons with no changes. However, we find no evidence for that: for example, mean log expenditures for non-switchers are 7.19 while they are 7.16 for switchers.
} 
results are consistent with the fact that the demand for public services increases with income. It is also interesting to note that several control variables flip sign once we include canton fixed effects. For example, the coefficients on population and the size of the industrial sector are negative without fixed effects but positive for the within estimator.

\subsection{Substitution across Levels of Government?}

The direct control of voters at the canton level might also affect lower levels of governments. Smaller governments at the canton level might decrease local spending either because citizens prefer less government in general or because local revenues are constrained by canton resources. There could however be the opposite effect. Canton politicians that face voter control might simply try to delegate spending to the local level. In that case, canton and local spending would be substitutes. The previous literature has found evidence that direct democracy decrease canton spending but increases local spending (for example, Feld, Schaltegger and Schnellenbach, 2008; Matsusaka, 1995). Our raw data (see table 2) also suggests that cantons with mandatory budget referendum might rely more on local governments to provide public goods and services.

To test more formally whether institutional constraints increase or decrease spending at lower levels of government, table 4 studies how direct democratic institutions at the canton level affect spending at the local level. The dependent variable is now the log of local spending in a canton per capita.

We first only include year effects (column (1)) and observable canton characteristics (column (2)). Based on both cross-sectional and temporal variation, we find that a mandatory budget referendum appears to increase spending at the local level by 20.3 percent. In contrast, weaker provisions for the voter initiative (a higher signature requirement) are associated with both more local and canton spending. 
The shift to more local government might however be spurious if there are other permanent institutional or taste differences between cantons. To account for these permanent differences, the third specification again adds canton fixed effects. The canton fixed effects are highly statistically significant (see last row) and have a striking effect on the coefficients of the direct democratic institutions: cantons that adopt or abolish the mandatory budget referendum do not rely more on local spending than other cantons without that institution.

Though cantons with stricter budget referendum have higher average local expenditures, this is entirely driven by permanent differences across cantons, not by the institution of the budget referendum per se. Higher costs for the voter initiative however continue to have a significantly positive effect on local spending. An increase in the signature requirement at the canton level by one standard deviation results in 8 percent higher local spending.

In contrast to previous studies, our fixed effects estimates indicate that stronger direct democratic institutions lower spending at the canton but do not increase spending at the local level. One interpretation of this result is that direct democracy does not substitute the public provision of goods and services to the local level.

The observed changes in canton and local spending might or might not imply a more decentralized structure of government. To test whether direct democracy indeed results in a more decentralized government, we use our centralization measure as the dependent variable. Specifically, the measure is calculated as $\frac{\text { CantonExp }}{\text { Canton+LocalExp }}$. If stronger direct democratic institutions decentralize spending, we should find a negative coefficient for the budget referendum and a positive coefficient for the voter initiative.

The results for our centralization measure are shown on the right-hand side of table 4 . Without controlling for permanent differences across cantons, we find results that a mandatory budget referendum indeed reduces centralization of government spending. Once we rely on 
within-canton variation using fixed effects, this result however disappears. Column (6) shows no statistically significant association between the mandatory budget referendum and the degree of government centralization.

For the voter initiative, we consistently find that higher costs of launching an initiative reduce government centralization (column (5) and (6) in table 4). For both institutions of direct democracy, we find no evidence that they shift spending to lower levels of government. These results highlight that it is important to control for permanent differences across cantons in order to identify the effect of political institutions on fiscal policy.

\subsection{Robustness Checks}

Our estimation approach might not capture all unobservable differences across cantons. Most importantly, we would expect that the demand for government has shifted over our 110 years period, for example, because of migration or changes in voting rights. To address this concern, we construct several measures for voter preferences, which we then add to our baseline regression.

Our first measure uses the voter support for more government as a proxy for the demand for government. To construct this variable, we use the fact that Switzerland allows for direct democratic participation at the federal level. ${ }^{16}$ Between 1890 and 2000, citizens of all cantons voted on 452 federal ballots. To assess the fiscal relevance of each proposition, we used the official documents prepared by the government, which are distributed to each citizen before the vote.

After careful study, we identified 108 propositions where the documents showed an unam-

\footnotetext{
${ }^{16}$ For example, citizens can initiate a partial or total revision of the federal constitution, vote on changes to the federal constitution or international treaties or request a referendum for all federal laws if 50,000 signatures are collected.
} 
biguous increase in expenditures, subsidies or taxes. Table A2 provides a list of the title of all votes with predictable fiscal consequences as well as the final outcome. The table shows that our fiscal policy relevant ballots span a broad range of political issues from the introduction of fuel taxes, government finances and environmental protection to education and health policy. For each vote, we use the approval rate in each canton for more government spending. To adjust for differences in approval rates across votes, we calculated the measure as the deviation from the overall mean for that proposition. Negative numbers for our preference measure thus imply that a canton was less supportive of higher spending than the average canton in that ballot. ${ }^{17}$

As an alternative measure for voters' demand for government, we use the strength of leftwing parties in canton parliaments. Left-wing parties are often associated with more redistribution and a larger government (for example, Tavares, 2004). Since representatives are elected by voters, we expect that party affiliation reflects voter preferences. The variable is calculated from the number of seats of left-wing parties divided by the total number of parliamentary seats in a canton. The advantage of this measure is that is available for many more years. Its disadvantage is that there might be many reasons why voters elect left-wing parties unrelated to government spending.

The data show that cantons with stronger direct democratic institutions are much less supportive of federal government spending. In contrast, we find no evidence that left-wing parties are necessarily weaker in cantons with stronger direct democracy. For both measures, there is substantial variation over time within the same canton. Since voter preferences are correlated with the budget referendum and also fluctuate over time, they might be an important source of omitted variable bias.

\footnotetext{
${ }^{17}$ We also experimented with alternative measures for approval rates. Our first alternative measure uses the percentage voting yes on a proposal instead of the deviation from the mean. Alternatively, we used a more conservative strategy where we included votes only if we could identify an increase in expenditures (rather than including also increases in taxes or subsidies). In both cases, the results were almost identical to the ones reported here.
} 
The first two columns of table 5 show the fixed effects estimator where we also include our measures of government demand. The top panel shows the results for canton expenditures and the bottom panel for local expenditures. All regressions include canton and year fixed effects as well as the same controls as before. Including controls for the demand for government has little effect on the coefficients of the direct democratic institutions. Canton expenditures continue to be significantly lower in cantons with a mandatory budget referendum, while local expenditures are lower or not affected. The coefficient on the voter initiative in turn has only a statistically significant effect if we include left-wing parties possibly because of fewer observations for the ballot measure.

We also expect that direct democracy might play a more important role for cantons with heterogeneous populations. In column (3), we therefore add measures of linguistic and religious heterogeneity calculated as one minus the Herfindahl index of concentration. Again, these additional controls for the demand for government have little effect on the coefficients.

Over our period, there were also important changes in voting rights. In particular, women were enfranchised and most cantons also switched to proportional representation during the twentieth century. We would expect that these electoral reforms shift the median voter and hence the demand for government. Column (4) shows that adding these two variables has little effect on our estimates.

We also check whether changes in other political institutions that are potentially correlated with direct democratic institutions and spending could drive our results. Some cantons also have a mandatory a law referendum, which requires every law to be approved by the electorate. Column (5) therefore adds a binary indicator equal to one if a canton has a mandatory law referendum in place and zero otherwise. The coefficients on the budget referendum become slightly more negative for canton and local expenditures while the coefficients on the voter 
initiative remain unchanged.

Similarly, we might suspect that more political decision-makers could increase expenditures independently of direct democracy. Column (6), which adds the size of the executive and the number of parliamentary seats to the specification, however shows that the effects of the budget referendum and voter initiative remain largely unchanged.

Finally, if spending is serially correlated, the standard errors of our fixed effects estimator would be too small. Given the small number of policy changes in our data, we address this concern by implementing the before-after estimator suggested by Bertrand et al. (2004). We first ran a regression of log expenditures on all our control variables and fixed effects. For the sample of cantons that changed their direct democratic institutions, we then aggregated the residual before and after the policy change. The coefficients in column (7) report the difference in this residual. While the estimates at the local level are not affected, the results at the canton level are somewhat weaker and only statistically significant at the 10 percent level.

We also checked that alternative specifications of the direct democratic variables do not affect our results (see table A3). Column (1) shows that the absolute number of signatures for the voter initiative, which assumes a fixed cost of collecting signatures, has a somewhat weaker effect on spending than if the signature requirement is measured in percentage of the eligible population. ${ }^{18}$ Column (2) relaxes the linear relationship between signature requirement and spending. We added variables equal to one if a canton's signature requirement is less than 1 percent, between 1 and 3 percent and above 3 percent respectively, and zero otherwise. The omitted category is cantons without a voter initiative in a given year. There are two noteworthy results: first, having a voter initiative in place substantially reduces spending at the canton and local level relative to a canton without the initiative. Second, higher signature requirements

\footnotetext{
${ }^{18}$ If we use the $\log$ of the number of signatures instead (not reported), we again find a strong positive effect. These estimates suggest that spending is more sensitive to changes at low levels of signatures requirements.
} 
(above 3 percent) reduce spending less than low signature requirements (below 1 percent). The difference are substantial and statistically significant, which is surprising given that signature requirements in Swiss cantons are on average much lower than, for example, in the United States.

There might also be important interaction effects between the budget referendum and voter initiative as argued by Feld and Matsusaka (2003). Column (3) confirms that the interaction effect between the two is negative also for our much longer sample period. The estimate implies that citizen control over the government through the mandatory budget referendum plays a more important role when the barriers to launch a voter initiative are high. Since our sample period spans more than a century, the relationship between direct democratic institutions and spending could have changed over time. For instance, voters might not always have been fiscally more conservative than politicians. In fact, we do not find statistically significant differences in voter support for government spending using our ballot measure between cantons with and without mandatory budget referendum prior to 1945 (not reported). Column (4) allows the coefficients on the budget referendum and voter initiative to vary before and after the end of the second World War. We find that the spending reduction of the budget referendum is a recent phenomenon. Before 1945, there is no effect while after 1945, there is a statistically significant negative effect of 4.8 percent. Similarly, we find that that a higher signature requirement increases spending only after 1945, while the effect is actually negative between 1890 and 1945 . These estimates are consistent with evidence from the United States in the twentieth century (Matsusaka, 1995; Matsusaka, 2000). ${ }^{19}$ Overall, this sections shows that the paper's main findings are robust across these alternative specifications.

\footnotetext{
${ }^{19}$ Interestingly however, voters in cantons with a low signature requirement (below the median) are fiscally more conservative than voters in cantons with high signature requirements throughout our sample period (18902000).
} 


\section{Instrumental Variable Approach}

\subsection{Policy Endogeneity}

Our results thus far show that the budget referendum and voter initiative constrain government spending even controlling for all permanent differences and other heterogeneity across cantons. A natural concern with our empirical strategy is that institutional changes in direct democracy are potentially endogenous and hence correlated with the residual in equation (1).

One way to assess the relevance of this concern is to analyze whether spending shifts prior to changes in direct democracy. To test for spending shifts, dummy variables denoting intervals four to six and one to three years prior to the institutional changes, and zero to four and more than five years after the institutional change were added to the specification in equation (1). The results shown in table A4 reveal strong spending trends prior to changes in the mandatory budget referendum and the signature requirement for the voter initiative.

It is not too surprising that spending shifts occur prior to changes in direct democratic institutions. We would expect citizens to demand a mandatory budget referendum or lower barriers to the voter initiative after periods of severe overspending in the eye of the voter. Table A5 provides some support for this argument. The top panel shows that the decision to adopt the mandatory budget referendum is positively correlated with expenditures two years prior to the change (column (2)). Similarly, a higher growth rate in spending increases the probability of adopting a mandatory budget referendum several years later (bottom panel). We find in contrast no evidence that past spending levels or growth rates affect the decision to abolish the budget referendum or change the signature requirement. Taken together, the evidence suggests that policy endogeneity is a concern. 


\subsection{Constitutional Initiative and Direct Democracy}

To eliminate the potential endogeneity bias, we require an instrument that drives changes direct democratic institutions in a canton. In Switzerland, the provisions that allow citizens to initiate new laws or vote on existing laws are regulated by the canton constitution. Hence, a candidate for an instrument is how costly it is to revise or amend the constitution. We use the provisions for the constitutional initiative which allows citizens to demand a revision or amend the existing constitution as our instrument. ${ }^{20}$

There are several reasons why the constitutional initiative might facilitate changes in the budget referendum and the voter initiative. The threat of a constitutional revision is a powerful tool for the political opposition or other groups not represented in the government to expand their political influence. This threat seems to be especially important when politicians are not adequately responding to voters' demand or changes therein.

Swiss constitutional history provides many examples where constitutional initiatives were used to expand democratic participation rights (see Curti, 1900; Kölz, 1992, 2004). In 1848, the new constitution of the Swiss federation not only adopted the constitutional initiative; it also required all cantons to allow for the constitutional initiative in the canton constitutions. This new institution became a powerful weapon of the "Democratic Movement", which advocated redistributive policies to offset rising economic inequalities in the population. Its first political success occurred in Basle County in 1863 when the law referendum and voter initiative were adopted; many more followed in other parts of Switzerland.

Likewise, the evolution of direct democracy since the late 19th century was strongly influenced by the provisions for the constitutional initiative (e.g. Kölz, 2004). In Grisons, for instance, the political opposition of young Democrats launched a constitutional initiative to

\footnotetext{
${ }^{20}$ The instrument is in the spirit of Poterba (1996) who advocates the use of constitutional rules to identify the causal effect of political institutions.
} 
strengthen direct democratic institutions. The initiative, which initially had trouble collecting enough signatures, proposed to lower the barriers for the voter initiative from 5,000 to 3,000. The revised constitution was approved by the electorate in 1891 (Metz, 1991). Similarly, a constitutional initiative in Schaffhouse in 1894 demanded the introduction of the mandatory budget referendum. The draft of the new constitution, which allowed a mandatory budget referendum for projects with extraordinary expenditures of 150,000 or recurrent expenditures of 15,000, was approved by the electorate in 1895 (Schneider, 1993). ${ }^{21}$

While all cantons allow for the constitutional initiative to amend or revise the constitution, they differ in the number of signatures required to launch such an initiative. Since the costs of a revision are increasing in the number of signatures, high signature requirements should reduce efforts to reform rules governing direct democratic participation in the constitution. Consequently, our instrument is measured as the signature requirement for changing the constitution in percentage of the eligible population. On average, 3.4 percent of the eligible population is required to get a constitutional initiative on the ballot.

Changes in direct democratic institutions are, indeed, correlated with the barriers for the constitutional initiative. In the raw data, a reduction in the signature requirement for the constitutional initiative by one percent increases the probability of adopting the budget referendum by 1.7 percent. Hence, a one standard deviation in the constitutional initiative (2.4) would decrease the adoption probability for the budget referendum by 5 percent. ${ }^{22}$

These simple averages, of course, do not take into account possible correlations between the constitutional initiative and other factors that might influence changes in the budget referendum

\footnotetext{
${ }^{21}$ Other examples of the role of the constitutional initiative for the voter initiative and mandatory budget referendum after 1890 can be found in Lucerne, Sankt Gallen, Schwyz, Uri, Valais and Zug (Möckli, 1987; Kölz, 2004).

${ }^{22}$ Alternatively, one can study the cantons where the expansion of direct democracy was not driven by constitutional initiatives. All four cantons (Aargau, Berne, Fribourg and Vaud) in which the expansion of direct democracy was actually proposed by the government have very high signature requirements for the constitutional initiative (for example, Berne with 15,000 signatures or Fribourg with 6,000 signatures in 1900).
} 
or the voter initiative. To allow for such considerations, we include a number of other controls that are possibly correlated with direct democracy and the constitutional initiative.

The constitutional initiative will affect both the costs of changing the budget referendum as well as the costs of launching a voter initiative. To separate the effect of the two institutions, we exploit the long time horizon of our data. As an additional instrument, we use the provisions for the mandatory budget referendum two decades earlier. Since institutions are persistent over time, we expect past arrangements for the mandatory budget referendum to affect the current institutional arrangement. Indeed, the raw correlation between the mandatory budget referendum today and twenty years earlier is 0.6.

The results of the first stage regressions are shown on the left-hand side of table 6 . The dependent variable is whether the canton has a budget referendum in column (1) and the signature requirement of the voter initiative in column (2). The first stage shows that a higher signature requirement for the constitutional initiative is associated with a higher barrier for the voter initiative and a reduction in the likelihood of a mandatory budget referendum. Not surprisingly, a budget referendum two decades earlier is positively correlated with the current provisions for the budget referendum.

How strong are these effects? If we raised the costs of launching a constitutional initiative by one standard deviation or 2.42 percent, the probability of adopting a mandatory budget referendum would be 18 percent lower. Also, the signature requirement for the voter initiative would be 1.84 percent higher. The statistics at the bottom of the table show that we have enough independent variation in the instruments. Shea's partial $R^{2}$ is 0.09 for the voter initiative and 0.11 for the budget referendum. In addition, the F-statistics of the instruments do suggest that our instruments are not weak (see Stock and Yogo, 2005). 


\subsection{Instrumental Variable Results}

The first stage shows a strong correlation between changes in direct democratic institutions and the barriers to launch a constitutional initiative. In order for the signature requirement of the constitutional initiative to serve as an instrument, it must be validly excluded from the spending equation.

This restriction is invalid if the constitutional initiative can be used to directly influence spending or revenue decisions. A closer look at the canton constitutions however shows that this is not the case. The constitutional initiative cannot be used to set spending levels or spending growth rates other than the spending thresholds for the optional or mandatory budget referendum.

The exclusion is also invalid if there are other variables that are both correlated with spending and the costs of a constitutional initiative. In particular, other political institutions fixed in the canton constitution might fall into that category, such as the number of political decisionmakers or changes in voting rights. While all time-invariant effects are absorbed in the canton fixed effects, changes in these institutions might still affect current expenditures. Therefore, we include as additional controls whether the canton has a law referendum, the size of the executive and the number of seats in a canton's parliament. In addition, we control for the adoption of women's suffrage and of proportional representation over the course of the twentieth century. Having included these institutional changes, canton characteristics and canton fixed effects, the barriers for a constitutional initiative appear to be plausible instruments.

The second-stage results are shown on the right-hand side of table 6 . We first report the least squares results for canton (column (3)) and local expenditures (column (6)) as a benchmark. For the budget referendum, we expect that least squares are smaller than instrumental variable estimates because reverse causality would bias the coefficients to zero. The instrumental variable 
estimates with three instruments are shown in columns (4) and (7). Our second set of estimates (columns (5) and (8)) also includes interaction effect between the signature requirements and year dummies. Hence, the constitutional initiative might be used to adopt a mandatory budget referendum in one period but abolish it at a later time (or vice versa).

For canton expenditures, we find that the mandatory budget referendum reduces canton spending by 13 to 19 percent. A one percent higher signature requirement for the voter initiative increases spending by 1.3 to 1.9 percent. ${ }^{23}$ As expected, the instrumental variable estimates are larger in magnitude than the least squares estimates. Are the instrumental variable estimates also plausible given that they are two to three times larger than the OLS results? There are at least three reasons why we consider our results reasonable. First, it is not uncommon in the literature on endogenous institutions that instrumental variables are several times larger than least squares (for example, Levitt, 1997; Levitt, 2002). Second, our estimates for the effects of direct democratic institutions are smaller than those found in comparable studies (Feld and Matsusaka (2003) report an equivalent of 20 percent lower expenditures for the budget referendum. Finally, one might suspect that large instrumental variable estimates indicate that the instruments should be included as controls in the second stage. However, the overidentification test reported at the bottom of table shows that we cannot reject the null hypothesis that the instruments can be excluded from the second stage.

For local expenditures, we find a negative or no effect of the budget referendum. For the basic set of instruments however, we do not pass the overidentification test $(\mathrm{p}=0.03)$. For the voter initiative, we find no effect on local spending irrespectively of which set of instruments we use. Hence, the instrumental variable estimates for local spending confirm our earlier results

\footnotetext{
${ }^{23}$ The F-statistics of the extended set of instruments suggest that the interaction effects are relatively weak instruments. While there is no general solution to this problem, the literature suggests the more robust Fuller's estimators for this case (Hahn, Hausman, and Kuersteiner, 2004). The results for the $\mathrm{k}=4$ estimator (not reported) show that the effect of the budget referendum is closer to 20 percent as suggested by the basic instrumental variable estimates in column (4).
} 
that direct democracy at the canton level does not shift spending to lower levels of government.

\section{Conclusion}

This paper presents strong evidence that the voter initiative and budget referendum reduce the size of government. Controlling for all permanent unobserved heterogeneity across cantons, we find that the mandatory budget referendum reduces state expenditures by 3.4 percent. If the signature requirement were decreased by one standard deviation, it would result in 2.4 percent less spending. Overall, our fixed effects estimates are much smaller than those reported in the literature identified from cross-sectional variation. In sharp contrast to previous studies (Matsusaka, 1995; Feld et al., 2008), we also show that a mandatory budget referendum at the state level is neither associated with less spending at the local level nor more decentralized public expenditures.

We provide evidence that the decision to adopt or abolish the budget referendum is systematically related to expenditures several years prior to the institutional change. To eliminate the bias from reverse causality and other omitted variables, we use the difficulty to launch an initiative for amending the constitution as an instrument. The results demonstrate that the adoption of a mandatory budget referendum decreases canton spending by 13-19 percent but have yet again no effect on local spending. In addition, a one standard deviation lower signature requirement for the initiative decreases canton spending between 6 and 9 percent, but has no effect on local government.

The results in this paper highlight the importance of accounting for unobserved differences and endogeneity when evaluating the effects of political institutions. They also provide strong support for the view that budget referendums is a highly effective tool to reduce government spending both at the state and at the local level. Increasing the barriers for the voter initiative 
also has important effects on canton spending, though not across levels of government.

Finally, we would like to point out that our results do not allow us to conclude that direct democratic participation is welfare-improving. To do so, we would need to compare the desired spending levels of the median voter with the costs of direct democratic participation to voters. While such an analysis is feasible, we leave an exploration of the welfare effects of direct democratic participation for future research.

\section{References}

[1] Acemoglu, D., S. Johnson and J. A. Robinson (2001), "The colonial origins of comparative development: An empirical investigation", American Economic Review, 91, 1369-1401.

[2] Acemoglu, D. and S. Johnson (2005), "Unbundling institutions," Journal of Political Economy, 113, 949-995.

[3] Bails, D. and M.A. Tieslau (2000), "The impact of fiscal constitutions on state and local expenditures," Cato Journal, 20, 2, 255-77.

[4] Betrand, M., E. Duflo and S. Mullainathan (2004), "How much should be trust differencein-difference estimates," Quarterly Journal of Economics, 119, 249-275.

[5] Besley, T. and A. Case (2000), "Unnatural experiments? Estimating the incidence of endogenous policies," Economic Journal, 110, F672-F694.

[6] Besley, T. and A. Case (2003), "Political institutions and policy outcomes: Evidence from the United States," Journal of Economic Literature, 41, 7-73.

[7] Besley, T. and S. Coate (2002), "Issue unbundling via citizens' initiatives," mimeo, London School of Economics.

[8] Bohn, H., and Inman, R. (1996) "Balanced budget rules and public deficits: Evidence from the U.S. states." NBER Working Paper No. 5533.

[9] Buchanan, J. and G. Tullock (1962), Calculus of consent: Logical foundations of constitutional democracy. Ann Arbor: University of Michigan Press.

[10] Bundesamt für Statistik (1891-2000), Statistisches Jahrbuch der Schweiz, Zurich:.Verlag Neue Zürcher Zeitung.

[11] Curti, T. (1900), Die schweizerischen Volksrechte, 1848 bis 1900, Berne: Muss Verlag

[12] Farnham, P.G. (1990), "The impact of citizen influence on local government expenditures," Public Choice, 64, 201-12. 
[13] Federal Department of Finance (various years), Öffentliche Finanzen der Schweiz, Bern, Switzerland.

[14] Feld, L.P. and J.G. Matsusaka (2003), "Budget referendums and government spending: Evidence from Swiss cantons," Journal of Public Economics, 87, 2703-24.

[15] Feld, L., C. Schaltegger and J. Schnellenbach (2008): "On government centralization and fiscal referendums: A theoretical model and evidence from Switzerland," European Economic Review, forthcoming.

[16] Funk, P. and C. Gathmann (2008), "Estimating the effect of direct democracy on fiscal policy: Preferences matter!", mimeo, Stanford University.

[17] Gerber, E.R. (1996), "Legislative response to the threat of popular initiatives," American Journal of Political Science, 40, 99-128.

[18] Hall, R.E. and C.I. Jones (1999), "Why do some countries produce so much more output than others?" Quarterly Journal of Economics, 114, 83-116.

[19] Hahn, J., Hausman, J., and Kuersteiner, G. (2004), "Estimation with weak instruments: Accuracy of higher order bias and MSE approximations", Econometrics Journal, 7 , 272-306.

[20] Hofferbert, R.I. (1976), Comparative socio-economic public policy and political data, 190060. Ann Arbor, MI: Inter-university Consortium for Political and Social Research, Study number 34 .

[21] Knight, B. (2000), "Supermajority voting requirements for tax increases: evidence from the states," Journal of Public Economics, 76, 41-56.

[22] Kölz, A. (1992), Neuere schweizerische Verfassungsgeschichte: Ihre Grundlinien vom Ende der alten Eidgenossenschaft bis 1848, Berne: Verlag Stämpfli.

[23] Kölz, A. (2004), Neuere schweizerische Verfassungsgeschichte: Ihre Grundlinien in Bund und Kantonen seit 1848, Berne: Verlag Stämpfli.

[24] Levitt, S. D. (1997), "Using electoral cycles in police hiring to estimate the effect of police on crime." American Economic Review, 87, 270-90.

[25] Levitt, S. D. (2002), "Using electoral cycles in police hiring to estimate the effect of police on crime: Reply." American Economic Review, 92, 1244-50.

[26] Matsusaka, J.G. (1995), "Fiscal effects of the voter initiative: evidence from the last 30 years," Journal of Political Economy, 103, 587-623

[27] Matsusaka, J.G. (2000), "Fiscal effect of the voter initiatives in the first half of the twentieth century," Journal of Law and Economics, 43, 619-50. 
[28] Matsusaka, J.G. (2004), For the many or the few: The initiative, public policy, and American democracy, Chicago: Chicago University Press.

[29] Metz, P. (1991), Geschichte des Kantons Graubünden, Band II: 1848-1914, Chur: Calven Verlag.

[30] Möckli, S. (1987): Die schweizerischen Landsgemeinde-Demokratien. Bern: Paul Haupt Verlag.

[31] Monnier, V. (1996), "Le référendum financier dans les cantons suisses au 19e siècle," in: Les Origines de la démocratie directe en Suisse, edited by A. Auer, Basel and Frankfurt a.M.: Helbing and Lichtenhahn.

[32] Moser, P. (2000), The political economy of democratic institutions. Cheltenham, UK.

[33] Peltzman, S. (1992), "Voters as fiscal conservatives," Quarterly Journal of Economics, 107, 327-61.

[34] Persson, T. and G. Tabellini (2003), Economic effects of constitutions, Cambridge, MA: MIT Press.

[35] Persson, T. and G. Tabellini (2004), "Constitutional rules and economic policy outcomes", American Economic Review, 94, 25-46.

[36] Pettersson-Lidbom, P. and B. Tyrefors (2007), "The policy consequences of direct versus representative democracy: A regression-discontinuity approach," mimeo, Stockholm School of Economics.

[37] Pommerehne, W. (1978), "Institutional approaches to public expenditures: Empirical evidence from Swiss municipalities," Journal of Public Economics, 9, 255-80.

[38] Poterba, J. (1994), "State responses to fiscal crises: The effects of budgetary institutions and politics," Journal of Political Economy, 102, 799-821.

[39] Poterba, J. (1996), "Budget institutions and fiscal policy in the US states," American Economic Review, 86, 395-400.

[40] Ritzmann-Blickenstorfer, H. (1996), Historische Statistik der Schweiz, Zurich: Chronos Verlag.

[41] Romer, Th. and H. Rosenthal (1979), "Bureaucrats versus voters: On the political economy of resource allocation by direct democracy," Quarterly Journal of Economics, 93, 56387.

[42] Rueben, K. (1997), "Tax limitations and government growth: The effect of the state tax and expenditure limits on state and local governments," manuscript, Public Policy Institute of California. 
[43] Schneider, C. (1993), "Die Volksrechte der Schaffhauser Kantonsverfassung - Entwicklung und Perspektiven," Schweizerisches Zentralblatt für Staats- und Verwaltungsrecht, 96, $389-415$.

[44] Schuppli, P. and R. Studer (2004), "Deflating Swiss prices over the last five centuries", mimeo, University of Oxford and Berne.

[45] Stock, J. H. and M. Yogo (2005), "Testing for weak instruments in linear IV regression.", in: Identification and Inference for Econometric Models: Essays in Honor of Thomas J. Rothenberg, edited by J.H. Stock and D.W.K. Andrews, Cambridge: Cambridge University Press.

[46] Tavares (2004), "Does right or left matter? Cabinets, credibility and fiscal adjustments," Journal of Public Economics, 88, 2447-2468.

[47] Trechsel, A. and U. Serdült (1999), Kaleidoskop Volksrechte: Die Institutionen der direkten Demokratie in den Schweizerischen Kantonen 1970-1996, Basel and München: Helbing and Lichtenhahn.

[48] Vatter, A. (2002), Kantonale Demokratien im Vergleich, Opladen: Leske and Budrich.

[49] Von Hagen, J. (1991), "A note on the empirical effectiveness of the formal fiscal restraint." Journal of Public Economics, 44, 199-210.

[50] Zax, J.S. (1989), "Initiatives and government expenditures," Public Choice, 63, 267-77.

\section{A Data Appendix}

This appendix describes the data sources and construction of variables. Our main outcome variables are canton expenditures, revenues, local expenditures and federal subsidies. All expenditure and revenue categories are expressed per capita and deflated to 2000 Swiss Francs using the annual consumer price index reported in Schuppli and Studer (2004). Canton expenditures and revenues are taken from the annual publication 'Statistisches Jahrbuch der Schweiz' for the years 1890 to 1950 and from 'Öffentliche Finanzen der Schweiz' for 1950 to 2000. Government expenditures and revenues are interpolated for two years with missing observations (1967 and 1968). Local expenditures are taken from 'Historical Statistics of Switzerland' and available for 1863, 1900, 1910, 1938 and annually since 1950. Data are missing in Nidwalden, Uri and Schaffhouse for 1863, 1900 and 1910 as well as in Obwalden, Solothurn, Appenzell-Innerrhode and Appenzell-Outerrhode in 1900 and 1910. Data for all cantons are missing in 1967 and 1968. Federal subsidies are revenues for cantons comprised of subsidies by the federal state for roads, education, welfare, agriculture and other areas. They are obtained from 'Historical Statistics of

Switzerland' prior to 1955 and from 'Öffentliche Finanzen der Schweiz' thereafter. The data are available for 1893, annually between 1915 and 1926, 1928, 1930, 1931, 1933, 1935-1937, 1940, 
1942, 1943, 1945, 1946, 1949 and annually since 1953, but missing between 1968 and 1977. All missing years were again obtained by linear interpolation.

Our main institutional variable is whether a canton has a mandatory budget referendum in place and the signature requirement for the voter initiative. We gathered this information by going though each canton's past and current constitutions (available at http://www.verfassungen.de/ch) as well as all relevant state laws. We used several published sources to validate and cross-check our coding of the institutional variables (Kölz, 2004; Monnier, 1996; Ritzmann-Blickernstorfer, 1996; Trechsel and Serdült, 1999; Vatter, 2002). If in doubt, we contacted the respective cantonal Public Record Offices (Staatsarchive) to clarify any inconsistencies between the published sources.

Our measure is a binary indicator equal to one if the canton had a mandatory budget referendum in place in that year. The indicator is zero if the budget referendum was optional or the canton does not have one at all. All cantons allow for the voter initiative at the canton level. Most cantons adopted the voter initiative well before the beginning of our sample period in 1890. Three cantons adopted the voter initiative shortly thereafter: Geneva in 1891, Ticino in 1892 and Berne in 1893. The remaining three cantons adopted it in 1906 (Lucerne), 1907 (Valais) and 1921 (Fribourg) respectively. The voter initiative is measured as the number of signatures for launching an initiative measured in percentage of the eligible population.

As additional control, we also look at the effect of the mandatory law referendum, which requires all canton laws to be approved by the electorate. The variable for the law referendum is a binary indicator if a canton has a mandatory law referendum in place and zero otherwise. Information on voter support for more spending is collected from the online database of all federal votes held between 1890 and today (http://www.admin.ch/ch/d/pore/va/vab_2_2_4_1.html).

Our preference measure is constructed as the percentage of votes in each canton in favor of propositions that would increase spending if approved. To identify the relevant fiscal policy votes, we used the documents produced by the federal government, which contain the arguments for and against a proposition and, most importantly, its estimated financial consequences, i.e. whether and by how much expenditures or taxes would increase if the proposition was approved. These are available online at http://www.ads.bar.admin.ch/ADS/showHome.do. Our second preference measure is calculated from the number of seats held by left-wing parties divided by the number of seats in the canton parliament. Both are compiled from Hofferbert (1967), the 'Statistisches Jahrbuch der Schweiz', information from old constitutions and information provided by each canton's Public Record Office. Left-wing party seats are missing for two cantons (Appenzell-Innerrhode and Appenzell-Outerrhode). No party seat information is available prior to 1943 for Nidwalden and prior to 1966 for Obwalden. In many cantons, there were no defined party affiliations in the late 19th and early 20th century. For seven cantons (Basle City, Geneva, Neuchatel, Lucerne, Solothurn, Schwyz and Zug), we have party affiliation over the whole period; for seven more (Aargau, Saint Gallen, Zurich, Basle County, Fribourg, Thurgau 
and Grisons) we have information since the 1910s. Information in four cantons (Berne, Glarus, Ticino and Valais) is available since the 1920s and for the remaining three since the early 1930s.

Most of our control variables are taken from the decennial Census as reported in 'Historical Statistics of Switzerland', Hofferbert (1976) and 'Statistisches Jahrbuch der Schweiz'; the data are available for 1888, 1900, 1910, 1920, 1930, 1941, 1950, 1960, 1970, 1980, 1990 and 2000. The population in each canton is from 'Statistisches Jahrbuch der Schweiz' and available annually since 1888. Population density is measured as the log of a canton's population. The variable urban measures the percentage of the population that lives in cities above 10,000 inhabitants. The data is taken from 'Historical Statistics of Switzerland' and 'Statistisches Jahrbuch der Schweiz' and available for 1890, 1894, 1898, 1903, for each decade between 1910 and 1960 as well as 1962, 1969, 1974, 1979, 1984, 1990 and 2000. The information on the population in different age groups (below 20, between 20 and 64 and above 65), the number of foreigners and religious affiliation is from the decennial Census. All three variables are expressed as percentage of the total population. Religious affiliation is calculated as the share of the population that is Protestant as opposed to Catholics and other religions. Finally, we also constructed a binary indicator whether the dominant language spoken in a canton is Italian or French.

We collected several labor market indicators to control for differences in economic activity across cantons. The total number employed and employment in the first (agriculture) and second (manufacturing) sector are from the decennial Census. The labor force participation rate is then calculated by dividing the number of people employed by the canton's total population. The distribution across sectors is calculated as percentage of total employment. We use three additional variables to control for income differences across cantons. The number of doctors is calculated per 1,000 inhabitants. The data is from 'Historical Statistics of Switzerland', Hofferbert (1976) and 'Statistisches Jahrbuch der Schweiz' and available for 1890, 1895, 1900, 1910, 1917, 1920, 1926, 1930, 1935, 1940, 1945, 1950, 1955, 1960, 1965, 1970, 1975. 1980. 1985, 1990, 1995 and 2000. Infant mortality denotes the number of children that died before reaching age one and is expressed per 100,000 births. The data for births and infant mortality is available annually since 1890 and taken from 'Historical Statistics of Switzerland'. Car ownership is calculated as number of cars per population and is from 'Historical Statistics of Switzerland' and 'Statistisches Jahrbuch der Schweiz'. It is zero before the first cars emerged in 1910 and positive thereafter. Data on cars owned is available for 1910, 1914, 1917, 1923, 1929, 1934, 1939, 1945, 1947, 1950, 1954, 1958, 1962, 1966, 1970, 1975, 1978, 1982, 1986 and annually since 1990. We used linear interpolation for missing years between two data points. We did not extrapolate missing data back to our starting year in 1890. 
Table 1: Direct Democratic Instruments in Swiss Cantons in 2000

\begin{tabular}{|c|c|c|c|c|}
\hline & $\begin{array}{l}\text { Mandatory } \\
\text { Budget } \\
\text { Referendum } \\
\end{array}$ & $\begin{array}{c}\text { Changes in } \\
\text { Mandatory } \\
\text { Budget Referendum }\end{array}$ & $\begin{array}{c}\text { Signature } \\
\text { Requirement } \\
\text { Voter Initiative } \\
\end{array}$ & $\begin{array}{c}\text { Changes in } \\
\text { Signature Requirement } \\
\text { of Voter Initiative }\end{array}$ \\
\hline Aargau (AG) & No & Abolish (1982) & 3,000 & Decrease (1982) \\
\hline Appenzell Outerrhode (AR) & Yes & No & 300 & Increase (1995) \\
\hline Appenzell Innerrhode (AI) & Yes & Adopt (1979) & 1 & No \\
\hline Basle County (BL) & No & Adopt (1892), Abolish (1945) & 1,500 & No \\
\hline Basle City (BS) & No & No & 4,000 & Increase (1950; 1975) \\
\hline Berne (BE) & No & Adopt (1893), Abolish (1995) & 15,000 & Increase (1995) \\
\hline Fribourg (FR) & Yes & Adopt (1972) & 6,000 & No \\
\hline Geneva (GE) & No & Adopt (1927), Abolish (1931) & 10,000 & Increase $(1936,1950)$ \\
\hline Glarus (GL) & Yes & No & 1 & No \\
\hline Grisons (GR) & Yes & No & 3,000 & Decrease (1893) \\
\hline Lucerne (LU) & Yes & Adopt (1969) & 4,000 & No \\
\hline Neuchatel (NE) & Yes & Adopt (1949), Abolish (2000) & 6,000 & Increase (1959) \\
\hline Nidwalden (NW) & Yes & Adopt (1913) & 250 & Increase (1996) \\
\hline Obwalden (OW) & No & Adopt (1902), Abolish (1998) & 500 & Increase (1998) \\
\hline Schaffhouse (SH) & Yes & Adopt (1895) & 1,000 & No \\
\hline Schwyz (SZ) & Yes & No & 2,000 & No \\
\hline Solothum (SO) & Yes & No & 3,000 & Increase (1977) \\
\hline St. Gallen (SG) & Yes & Adopt (1929) & 4,000 & No \\
\hline Ticino $(\mathrm{TI})$ & No & No & 7,000 & Increase (1970) \\
\hline Thurgau (TG) & Yes & No & 4,000 & Increase (1990) \\
\hline Uri (UR) & Yes & No & 600 & Increase $(1929,1955,1997)$ \\
\hline Vaud (VD) & No & Abolish (1948), Adopt (1998) & 12,000 & Increase (1961) \\
\hline Valais (VS) & No & Abolish (1994) & 4,000 & Increase (1973), Decrease (1994) \\
\hline Zurich $(\mathrm{ZH})$ & No & Abolish (1999) & 10,000 & Increase (1979) \\
\hline Zug $(Z G)$ & No & No & 2,000 & Decrease (1894), Increase (1991) \\
\hline
\end{tabular}


Table 2: Summary Statistics by Institutional Regime

\begin{tabular}{|c|c|c|c|c|c|}
\hline & \multicolumn{2}{|c|}{ Mandatory Referendum } & \multicolumn{2}{|c|}{ No Mandatory Referendum } & \multirow{2}{*}{$\begin{array}{l}\text { T Statistic } \\
\text { Difference } \\
\end{array}$} \\
\hline & Mean & Std. Dev & Mean & Std. Dev & \\
\hline \multicolumn{6}{|l|}{ Fiscal Policy } \\
\hline Expenditures per capita (log) & 7.15 & 1.24 & 7.18 & 1.31 & 0.5 \\
\hline Revenues per capita (log) & 7.13 & 1.25 & 7.15 & 1.31 & 0.4 \\
\hline Local expenditures in canton (log) & 7.07 & 1.19 & 6.63 & 1.13 & -9.5 \\
\hline Degree of Centralization & 53.72 & 12.45 & 61.38 & 17.15 & -2.9 \\
\hline \multicolumn{6}{|l|}{ Political Institutions } \\
\hline Signature requirement initiative (\%) & 2.39 & 3.17 & 4.20 & 6.44 & 9.9 \\
\hline Mandatory law referendum & 0.84 & 0.37 & 0.26 & 0.44 & -40.4 \\
\hline Size of Parliament & 115.67 & 55.74 & 111.42 & 43.19 & -2.0 \\
\hline Size of Executive & 6.44 & 1.44 & 6.75 & 1.32 & 5.7 \\
\hline Proportional Representation & 0.53 & 0.50 & 0.76 & 0.43 & 11.7 \\
\hline Women Suffrage Adopted? & 0.28 & 0.45 & 0.26 & 0.44 & -1.5 \\
\hline \multicolumn{6}{|l|}{ Control Variables } \\
\hline Language: non-German & 0.14 & 0.35 & 0.43 & 0.49 & 17.9 \\
\hline Age 0 to $19(\%)$ & 34.22 & 6.11 & 32.99 & 7.83 & -4.6 \\
\hline Age 20 to $39(\%)$ & 29.66 & 2.25 & 30.58 & 2.94 & 9.3 \\
\hline Age 40 to $64(\%)$ & 26.50 & 3.07 & 27.33 & 4.04 & 6.1 \\
\hline Age 65 and Above (\%) & 9.63 & 3.47 & 9.10 & 3.70 & -3.7 \\
\hline Log population & 11.61 & 1.13 & 11.69 & 1.06 & 1.7 \\
\hline Urban population (\%) & 19.01 & 19.07 & 37.77 & 31.02 & 19.7 \\
\hline Federal subsidies (log) & 5.43 & 1.21 & 5.16 & 1.07 & -5.7 \\
\hline Employment in primary sector (\%) & 21.04 & 12.91 & 18.89 & 15.44 & -3.9 \\
\hline Employment in secondary sector (\%) & 44.66 & 11.96 & 41.54 & 9.81 & -7.0 \\
\hline Labor force participation & 39.92 & 7.15 & 42.13 & 8.36 & 6.9 \\
\hline Doctors per 1,000 inhabitants & 0.81 & 0.35 & 1.05 & 0.64 & 12.6 \\
\hline Cars owned (\%) & 12.58 & 16.50 & 11.70 & 17.01 & -1.3 \\
\hline Infant mortality rate & 59.77 & 106.05 & 61.20 & 89.29 & 0.4 \\
\hline Linguistic Heterogeneity & 0.20 & 0.23 & 0.21 & 0.16 & 1.9 \\
\hline Religious Heterogeneity & 0.34 & 0.20 & 0.34 & 0.20 & -0.3 \\
\hline
\end{tabular}


Table 3: Direct Democracy and Fiscal Policy: Fixed Effects

\begin{tabular}{|c|c|c|c|c|c|c|}
\hline & \multicolumn{3}{|c|}{ Canton Expenditures } & \multicolumn{3}{|c|}{ Canton Revenues } \\
\hline & $(1)$ & $(2)$ & (3) & (4) & $(5)$ & (6) \\
\hline \multirow[t]{2}{*}{ Budget Referendum } & -0.267 & -0.093 & -0.034 & -0.259 & -0.086 & -0.018 \\
\hline & $(0.017)^{\star \star \star}$ & $(0.013)^{\star \star \star}$ & $(0.014)^{\star \star}$ & $(0.017)^{\star \star \star}$ & $(0.014)^{\star \star \star}$ & $(0.015)$ \\
\hline \multirow[t]{2}{*}{ Signature Requirement Initiative } & -0.01 & 0.004 & 0.005 & -0.011 & 0.005 & 0.006 \\
\hline & $(0.002)^{\star \star \star}$ & $(0.002)^{\star \star}$ & $(0.001)^{\star \star \star}$ & $(0.002)^{\star \star \star}$ & $(0.002)^{\star \star \star}$ & $(0.002)^{\star \star \star}$ \\
\hline \multirow[t]{2}{*}{ Log Population } & & -0.122 & 0.122 & & -0.128 & 0.135 \\
\hline & & $(0.008)^{\star \star \star}$ & $(0.050)^{\star \star}$ & & $(0.008)^{\star \star \star}$ & $(0.054)^{\star \star}$ \\
\hline \multirow[t]{2}{*}{$\%$ Age 20 to 39 Years } & & 0.056 & -0.005 & & 0.048 & -0.016 \\
\hline & & $(0.005)^{\star \star \star}$ & $(0.004)$ & & $(0.005)^{\star \star \star}$ & $(0.004)^{\star \star \star}$ \\
\hline \multirow[t]{2}{*}{$\%$ Age 40 to 64 Years } & & 0.039 & 0.002 & & 0.035 & -0.002 \\
\hline & & $(0.004)^{\star \star \star}$ & $(0.003)$ & & $(0.004)^{\star \star \star}$ & $(0.004)$ \\
\hline \multirow{2}{*}{$\%$ Above Age 65} & & 0.006 & -0.04 & & 0.008 & -0.033 \\
\hline & & $(0.005)$ & $(0.006)^{\star \star \star}$ & & $(0.005)$ & $(0.007)^{\star \star \star}$ \\
\hline \multirow[t]{2}{*}{ \% Urban Population } & & 0.002 & 0.002 & & 0.002 & 0.002 \\
\hline & & $(0.000)^{\star \star \star}$ & $(0.001)^{\star \star \star}$ & & $(0.000)^{\star \star \star}$ & $(0.001)^{\star \star \star}$ \\
\hline \multirow[t]{2}{*}{ Federal Subsidies (log) } & & 0.138 & 0.146 & & 0.117 & 0.128 \\
\hline & & $(0.011)^{\star \star \star}$ & $(0.010)^{\star \star \star}$ & & $(0.012)^{\star \star \star}$ & $(0.010)^{\star \star \star}$ \\
\hline \multirow[t]{2}{*}{ \% Employed Agriculture } & & -0.014 & 0.004 & & -0.018 & -0.001 \\
\hline & & $(0.002)^{\star \star \star}$ & $(0.002)^{\star}$ & & $(0.002)^{\star \star \star}$ & $(0.002)$ \\
\hline \multirow[t]{2}{*}{ \% Employed Industry } & & -0.006 & 0.016 & & -0.007 & 0.015 \\
\hline & & $(0.001)^{\star \star \star}$ & $(0.002)^{\star \star \star}$ & & $(0.001)^{\star \star \star}$ & $(0.002)^{\star \star \star}$ \\
\hline \multirow[t]{2}{*}{ Labor Force Participation (\%) } & & -0.01 & -0.018 & & -0.011 & -0.018 \\
\hline & & $(0.001)^{\star \star \star}$ & $(0.001)^{\star \star \star}$ & & $(0.001)^{\star \star \star \star}$ & $(0.001)^{\star \star \star}$ \\
\hline \multirow[t]{2}{*}{ Doctors (per 1,000 inhabitants) } & & 0.089 & -0.164 & & 0.057 & -0.215 \\
\hline & & $(0.029)^{\star \star \star}$ & $(0.027)^{\star \star \star}$ & & $(0.030)^{\star}$ & $(0.029)^{\star \star \star}$ \\
\hline \multirow[t]{2}{*}{ Car Ownership per capita (\%) } & & 0.023 & 0.013 & & 0.023 & 0.012 \\
\hline & & $(0.002)^{\star \star \star}$ & $(0.002)^{\star \star \star}$ & & $(0.003)^{\star \star \star}$ & $(0.002)^{\star \star \star}$ \\
\hline \multirow[t]{2}{*}{ Infant Mortality Rate } & & -0.002 & -0.001 & & -0.002 & -0.001 \\
\hline & & $(0.000)^{\star \star \star}$ & $(0.000)^{\star \star \star}$ & & $(0.000)^{\star \star \star}$ & $(0.000)^{\star \star \star}$ \\
\hline Year Fixed Effects & Yes & Yes & Yes & Yes & Yes & Yes \\
\hline Age Structure of Canton & No & Yes & Yes & No & Yes & Yes \\
\hline Canton Fixed Effects & No & No & Yes & No & No & Yes \\
\hline Observations & 2524 & 2524 & 2524 & 2524 & 2524 & 2524 \\
\hline R-squared & 0.90 & 0.96 & 0.98 & 0.90 & 0.95 & 0.98 \\
\hline Joint Significance Canton FE & & & 110.4 & & & 98.1 \\
\hline (p value) & & & $<0.001$ & & & $<0.001$ \\
\hline
\end{tabular}

Notes: The dependent variable in columns (1)-(3) is log annual canton per capita expenditures and log annual canton per capita revenues in columns (4)-(6). The first specification (columns (1) and (4)) include only whether a canton has a mandatory budget referendum in place and the signature requirement for the voter initiative as well as year dummies. The second specification adds log population, the percentage of the population in different age groups (20-39, 40-64, 65 and over with age 0-19 as the omitted category), the percentage of the population living in cities with more than 10,000 inhabitants, the percentage of workers employed in agriculture and industry, the log per capita federal subsidies to a canton, labor force participation rate, infant mortality rate, the per capita ownership of cars and the number of doctors per 1,000 inhabitants. Robust standard errors are reported in parentheses. ${ }^{*} p<0.1$, ${ }^{\star *} p<0.05$ and ${ }^{* \star *} p<0.01$. The last two rows in columns (3) and (6) report the Fstatistic and $p$-value for the joint significance of the canton fixed effects. 
Table 4: Direct Democracy and Decentralization: Fixed Effects

\begin{tabular}{|c|c|c|c|c|c|c|}
\hline & & al Expenditc & & Cent & alization $\mathrm{Me}$ & sure \\
\hline & (1) & $(2)$ & (3) & $(4)$ & $(5)$ & (6) \\
\hline Budget Referendum & $\begin{array}{c}0.219 \\
(0.025)^{\star \star \star}\end{array}$ & $\begin{array}{c}0.203 \\
(0.024)^{\star \star \star}\end{array}$ & $\begin{array}{l}-0.024 \\
(0.024)\end{array}$ & $\begin{array}{c}-8.96 \\
(0.578)^{\star \star \star}\end{array}$ & $\begin{array}{c}-6.302 \\
(0.552)^{\star \star \star}\end{array}$ & $\begin{array}{c}-0.372 \\
(0.517)\end{array}$ \\
\hline Signature Requirement Initiative & $\begin{array}{c}0.002 \\
(0.003)\end{array}$ & $\begin{array}{c}0.019 \\
(0.003)^{\star \star \star}\end{array}$ & $\begin{array}{c}0.017 \\
(0.003)^{\star \star \star}\end{array}$ & $\begin{array}{c}-0.274 \\
(0.067)^{\star \star \star}\end{array}$ & $\begin{array}{c}-0.366 \\
(0.074)^{\star \star \star}\end{array}$ & $\begin{array}{c}-0.333 \\
(0.055)^{\star \star \star}\end{array}$ \\
\hline Log Population & & $\begin{array}{c}0.139 \\
(0.014)^{\star \star \star}\end{array}$ & $\begin{array}{c}-0.911 \\
(0.090)^{\star \star *}\end{array}$ & & $\begin{array}{c}-4.882 \\
(0.330)^{\star \star \star}\end{array}$ & $\begin{array}{c}14.947 \\
(1.912)^{\star \star \star}\end{array}$ \\
\hline \% Urban Population & & $\begin{array}{c}-0.003 \\
(0.001)^{\star \star \star}\end{array}$ & $\begin{array}{c}0.006 \\
(0.001)^{\star \star \star}\end{array}$ & & $\begin{array}{c}0.032 \\
(0.018)^{\star}\end{array}$ & $\begin{array}{c}-0.069 \\
(0.026)^{\star \star \star}\end{array}$ \\
\hline Federal Subsidies (log) & & $\begin{array}{c}0.016 \\
(0.021)\end{array}$ & $\begin{array}{c}-0.062 \\
(0.018)^{\star \star \star}\end{array}$ & & $\begin{array}{c}3.389 \\
(0.482)^{\star \star \star}\end{array}$ & $\begin{array}{c}4.388 \\
(0.383)^{\star \star \star}\end{array}$ \\
\hline \% Employed Agriculture & & $\begin{array}{c}-0.023 \\
(0.003)^{\star \star \star}\end{array}$ & $\begin{array}{c}-0.019 \\
(0.003)^{\star \star \star}\end{array}$ & & $\begin{array}{c}0.017 \\
(0.069)\end{array}$ & $\begin{array}{c}0.289 \\
(0.072)^{\star \star \star}\end{array}$ \\
\hline \% Employed Industry & & $\begin{array}{l}-0.002 \\
(0.002)\end{array}$ & $\begin{array}{c}0.011 \\
(0.004)^{\star \star \star}\end{array}$ & & $\begin{array}{c}-0.287 \\
(0.055)^{\star \star \star}\end{array}$ & $\begin{array}{c}-0.152 \\
(0.076)^{\star \star}\end{array}$ \\
\hline Labor Force Participation (\%) & & $\begin{array}{c}0.009 \\
(0.002)^{\star \star \star}\end{array}$ & $\begin{array}{l}-0.001 \\
(0.002)\end{array}$ & & $\begin{array}{c}-0.296 \\
(0.054)^{\star \star \star}\end{array}$ & $\begin{array}{c}-0.250 \\
(0.050)^{\star \star \star}\end{array}$ \\
\hline Doctors (per 1,000 inhabitants) & & $\begin{array}{c}-0.531 \\
(0.051)^{\star \star \star}\end{array}$ & $\begin{array}{c}-0.416 \\
(0.047)^{\star \star \star}\end{array}$ & & $\begin{array}{c}5.325 \\
(1.173)^{\star \star \star}\end{array}$ & $\begin{array}{c}-2.531 \\
(0.984)^{\star \star}\end{array}$ \\
\hline Car Ownership per capita (\%) & & $\begin{array}{c}0.048 \\
(0.004)^{\star \star \star}\end{array}$ & $\begin{array}{c}0.043 \\
(0.004)^{\star \star \star}\end{array}$ & & $\begin{array}{c}-1.057 \\
(0.102)^{\star \star \star}\end{array}$ & $\begin{array}{c}-0.962 \\
(0.085)^{\star \star \star}\end{array}$ \\
\hline Infant Mortality Rate & & $\begin{array}{l}-0.0003 \\
(0.0002)\end{array}$ & $\begin{array}{l}-0.0002 \\
(0.0002)\end{array}$ & & $\begin{array}{c}0.042 \\
(0.004)^{\star \star \star}\end{array}$ & $\begin{array}{c}0.030 \\
(0.003)^{\star \star \star}\end{array}$ \\
\hline Year Fixed Effects & Yes & Yes & Yes & Yes & Yes & Yes \\
\hline Age Structure of Canton & No & Yes & Yes & No & Yes & Yes \\
\hline Canton Fixed Effects & No & No & Yes & No & No & Yes \\
\hline Observations & 2410 & 2410 & 2410 & 2410 & 2410 & 2410 \\
\hline R-squared & 0.77 & 0.84 & 0.93 & 0.16 & 0.44 & 0.79 \\
\hline Joint Significance Canton FE & & & 117.1 & & & 152.8 \\
\hline ( $p$ value) & & & $<0.001$ & & & $<0.001$ \\
\hline
\end{tabular}

Notes: The dependent variable in the first three columns is log per capita expenditures of local communities in each canton; in columns (4) to (6), it is the percentage of per capita expenditures at the canton level calculated as canton spending/(canton+local spending). For three cantons (Uri, Schaffhouse and Nidwalden), local expenditures were only available since 1938 . See the notes to Table 3 for an explanation of the independent variables included in the estimation. Robust standard errors are reported in parentheses. * $p<0.1$, ${ }^{*}$ $p<0.05$ and ${ }^{\star * \star} p<0.01$. The last two rows in columns (3) and (6) report the F-statistic and p-value for the joint significance of the canton fixed effects. 
Table 5: Robustness Checks

\begin{tabular}{|c|c|c|c|c|c|c|c|}
\hline & $\frac{\begin{array}{l}\text { Voter } \\
\text { Preferences }\end{array}}{\frac{\text { (ballot support) }}{(1)}}$ & $\frac{\frac{\text { Voter }}{\text { Preferences }}}{\frac{\text { (left parties) }}{(2)}}$ & $\begin{array}{c}\frac{\text { Population }}{\text { Heterogeneity }} \\
\text { (3) }\end{array}$ & $\frac{\text { Change in }}{\frac{\text { Voting }}{\frac{\text { Rights }}{(4)}}}$ & $\begin{array}{l}\frac{\text { Mandatory }}{\text { Law }} \\
\frac{\text { Referendum }}{(5)}\end{array}$ & 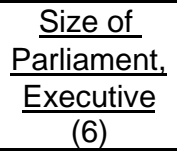 & $\begin{array}{l}\frac{\text { Account for }}{\text { Serial }} \\
\frac{\text { Correlation }}{(7)}\end{array}$ \\
\hline \multicolumn{8}{|l|}{ Y: Canton Expenditures } \\
\hline$\overline{\text { Budget Referendum }}$ & $\begin{array}{c}-0.045 \\
(0.015)^{\star \star}\end{array}$ & $\begin{array}{c}-0.042 \\
(0.013)^{\star *}\end{array}$ & $\begin{array}{c}-0.04 \\
(0.014)^{\star *}\end{array}$ & $\begin{array}{c}-0.034 \\
(0.014)^{\star \star}\end{array}$ & $\begin{array}{c}-0.049 \\
(0.014)^{\star \star \star}\end{array}$ & $\begin{array}{c}-0.025 \\
(0.014)^{\star}\end{array}$ & $\begin{array}{c}-0.017 \\
(0.009)^{\star}\end{array}$ \\
\hline Signature Requirement Initiative & $\begin{array}{c}0.006 \\
(0.004)\end{array}$ & $\begin{array}{c}0.005 \\
(0.002)^{\star \star}\end{array}$ & $\begin{array}{c}0.004 \\
(0.001)^{\star \star \star}\end{array}$ & $\begin{array}{c}0.005 \\
(0.001)^{\star \star \star}\end{array}$ & $\begin{array}{c}0.005 \\
(0.001)^{\star \star \star}\end{array}$ & $\begin{array}{c}0.005 \\
(0.002)^{\star \star \star}\end{array}$ & $\begin{array}{c}0.002 \\
(0.001)^{\star}\end{array}$ \\
\hline Voter Preferences & $\begin{array}{c}0.003 \\
(0.001)^{\star \star}\end{array}$ & $\begin{array}{c}0 \\
(0.001)\end{array}$ & & & & & \\
\hline Year Fixed Effects & Yes & Yes & Yes & Yes & Yes & Yes & Yes \\
\hline Canton Fixed Effects & Yes & Yes & Yes & Yes & Yes & Yes & Yes \\
\hline Canton Characteristics & Yes & Yes & Yes & Yes & Yes & Yes & Yes \\
\hline Observations & 1349 & 2399 & 2524 & 2524 & 2524 & 2524 & 1514 \\
\hline R Squared & 0.98 & 0.98 & 0.98 & 0.98 & 0.98 & 0.98 & \\
\hline \multicolumn{8}{|l|}{ Y: Local Expenditures } \\
\hline$\overline{\text { Budget Referendum }}$ & $\begin{array}{l}-0.043 \\
(0.031)\end{array}$ & $\begin{array}{c}-0.051 \\
(0.017)^{\star \star}\end{array}$ & $\begin{array}{c}-0.024 \\
(0.024)\end{array}$ & $\begin{array}{c}-0.024 \\
(0.024)\end{array}$ & $\begin{array}{c}-0.036 \\
(0.025)\end{array}$ & $\begin{array}{c}0.011 \\
(0.024)\end{array}$ & $\begin{array}{c}-0.016 \\
(0.016)\end{array}$ \\
\hline Signature Requirement Initiative & $\begin{array}{c}0.019 \\
(0.013)\end{array}$ & $\begin{array}{c}0.016 \\
(0.003)^{\star \star}\end{array}$ & $\begin{array}{c}0.016 \\
(0.003)^{\star \star \star}\end{array}$ & $\begin{array}{c}0.017 \\
(0.003)^{\star \star \star}\end{array}$ & $\begin{array}{c}0.017 \\
(0.003)^{\star \star \star}\end{array}$ & $\begin{array}{c}0.012 \\
(0.003)^{\star \star \star}\end{array}$ & $\begin{array}{c}0.009 \\
(0.002)^{\star \star \star}\end{array}$ \\
\hline Voter Preferences & $\begin{array}{c}0.004 \\
(0.002)^{\star}\end{array}$ & $\begin{array}{c}0.377 \\
(0.116)^{\star \star}\end{array}$ & & & & & \\
\hline Year Fixed Effects & Yes & Yes & Yes & Yes & Yes & Yes & Yes \\
\hline Canton Fixed Effects & Yes & Yes & Yes & Yes & Yes & Yes & Yes \\
\hline Canton Characteristics & Yes & Yes & Yes & Yes & Yes & Yes & Yes \\
\hline Observations & 1322 & 1904 & 2410 & 2410 & 2410 & 2410 & 1438 \\
\hline R Squared & 0.94 & 0.96 & 0.93 & 0.93 & 0.93 & 0.94 & \\
\hline
\end{tabular}

Notes: The dependent variable in the top panel is the log of canton expenditures and the log of local expenditures in the bottom panel. Column (1) and (2) adds our preference measures (voter support for more government and the share of left-wing parties in canton parliaments respectively) to the baseline. Column (3) includes two measures of religious and linguistic heterogeneity. Column (4) controls for the introduction of female suffrage and proportional represention. Column (5) also controls for the mandatory law referendum while column (6) adds the size of executive and the size of parliament. Finally, column (7) implements the before-after estimator proposed by Betrand et al. (2004) to deal with serial correlation in the case of a small number of states. All specifications include year and canton fixed effects and the same controls as in column (3) in Table $3 .{ }^{*} p<0.1,{ }^{* \star} p<0.05$ and $* * \star p<0.01$. Robust standard errors in parentheses 
Table 6: Direct Democracy and Fiscal Policy: Instrumental Variables

\begin{tabular}{|c|c|c|c|c|c|c|c|c|}
\hline & First Stag & Results & $\underline{\text { Second St }}$ & e (Canton E & enditures) & Second S & e (Local Exp & ditures) \\
\hline & $\begin{array}{c}\text { Budget } \\
\text { Referendum } \\
(1) \\
\end{array}$ & $\begin{array}{c}\text { Voter } \\
\text { Initiative } \\
(2) \\
\end{array}$ & $\begin{array}{c}\text { OLS } \\
\text { Estimates } \\
(3) \\
\end{array}$ & $\begin{array}{c}\text { IV } \\
\text { Estimates } \\
(4) \\
\end{array}$ & $\begin{array}{c}\text { IV plus } \\
\text { Estimates } \\
(5) \\
\end{array}$ & $\begin{array}{c}\text { OLS } \\
\text { Estimates } \\
(6) \\
\end{array}$ & $\begin{array}{c}\text { IV } \\
\text { Estimates } \\
(7) \\
\end{array}$ & $\begin{array}{c}\text { IV plus } \\
\text { Estimates } \\
(8) \\
\end{array}$ \\
\hline Mandatory Budget Referendum & & & $\begin{array}{l}-0.049 \\
(0.011)^{\star \star \star}\end{array}$ & $\begin{array}{c}-0.19 \\
(0.041)^{\star \star \star}\end{array}$ & $\begin{array}{c}-0.127 \\
(0.029)^{\star \star \star}\end{array}$ & $\begin{array}{l}0.025 \\
(0.016)\end{array}$ & $\begin{array}{l}-0.128 \\
(0.055)^{\star \star}\end{array}$ & $\begin{array}{l}-0.049 \\
(0.037)\end{array}$ \\
\hline Signature Requirement Initiative & & & $\begin{array}{c}0.009 \\
(0.002)^{\star \star \star}\end{array}$ & $\begin{array}{c}0.019 \\
(0.008)^{\star \star}\end{array}$ & $\begin{array}{c}0.013 \\
(0.007)^{\star \star}\end{array}$ & $\begin{array}{c}0.02 \\
(0.003)^{\star \star \star}\end{array}$ & $\begin{array}{l}-0.006 \\
(0.010)\end{array}$ & $\begin{array}{l}-0.014 \\
(0.011)\end{array}$ \\
\hline Signature Requirement Constitutional Initiative & $\begin{array}{l}-0.094 \\
(0.025)^{\star \star \star}\end{array}$ & $\begin{array}{c}0.759 \\
(0.113)^{\star \star \star}\end{array}$ & & & & & & \\
\hline Signature Requirement Squared & $\begin{array}{c}0.008 \\
(0.002)^{\star \star \star}\end{array}$ & $\begin{array}{c}-0.01 \\
'(0.013)\end{array}$ & & & & & & \\
\hline Budget Referendum 20 Years Earlier & $\begin{array}{c}0.365 \\
(0.034)^{\star \star \star}\end{array}$ & $\begin{array}{c}0.425 \\
(0.128)^{\star \star \star}\end{array}$ & & & & & & \\
\hline Year Fixed Effects & Yes & Yes & Yes & Yes & Yes & Yes & Yes & Yes \\
\hline Canton Characteristics & Yes & Yes & Yes & Yes & Yes & Yes & Yes & Yes \\
\hline Canton Fixed Effects & Yes & Yes & Yes & Yes & Yes & Yes & Yes & Yes \\
\hline Observations & 2274 & 2274 & 2274 & 2274 & 2274 & 2190 & 2190 & 2190 \\
\hline R Squared & 0.76 & 0.69 & 0.98 & & & 0.96 & & \\
\hline Shea's Partial R Squared of First-Stage & 0.11 & 0.09 & & & & & & \\
\hline F-Statistic Excluded Instruments & 49.88 & 125.6 & & & & & & \\
\hline $\begin{array}{l}\text { Sargan statistic } \\
\text { ( } p \text { value) }\end{array}$ & & & & $\begin{array}{l}0.091 \\
0.76\end{array}$ & $\begin{array}{c}161.1 \\
0.85\end{array}$ & & $\begin{array}{l}9.68 \\
0.03\end{array}$ & $\begin{array}{c}146.4 \\
0.97\end{array}$ \\
\hline
\end{tabular}

Notes: The table reports instrumental variable results. The instruments for the budget referendum and signature requirement of the voter initiative are the signature requirement to launch a constitutional initiative (linear and quadratic term). Columns (1) and (2) show the first stage where the dependent variable is whether a canton has a mandatory budget referendum (column (1)) or the signature requirement for the voter initiative (column (2)). The dependent variable in columns (3) to (5) are log canton expenditures and log local expenditures in columns (6) to (8). Columns (3) and (6) show the least

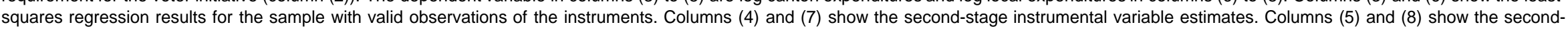
stage instrumental variables results where the effects of the constitutional initiative varies by year. All specifications include year and canton fixed effects, the same controls as in previous tables and the following additional controls: whether the canton has a mandatory law referendum, the number of seats in the canton parliament, the size of the executive, whether a canton had women's suffrage adopted and whether the canton parliament is elected according to proportional rule. Robust standard errors reported in parentheses. ${ }^{*} p<0.1,{ }^{* *} p<0.05$ and ${ }^{* \star *} p<0.01$. 
Figure 1: Map of Swiss Cantons

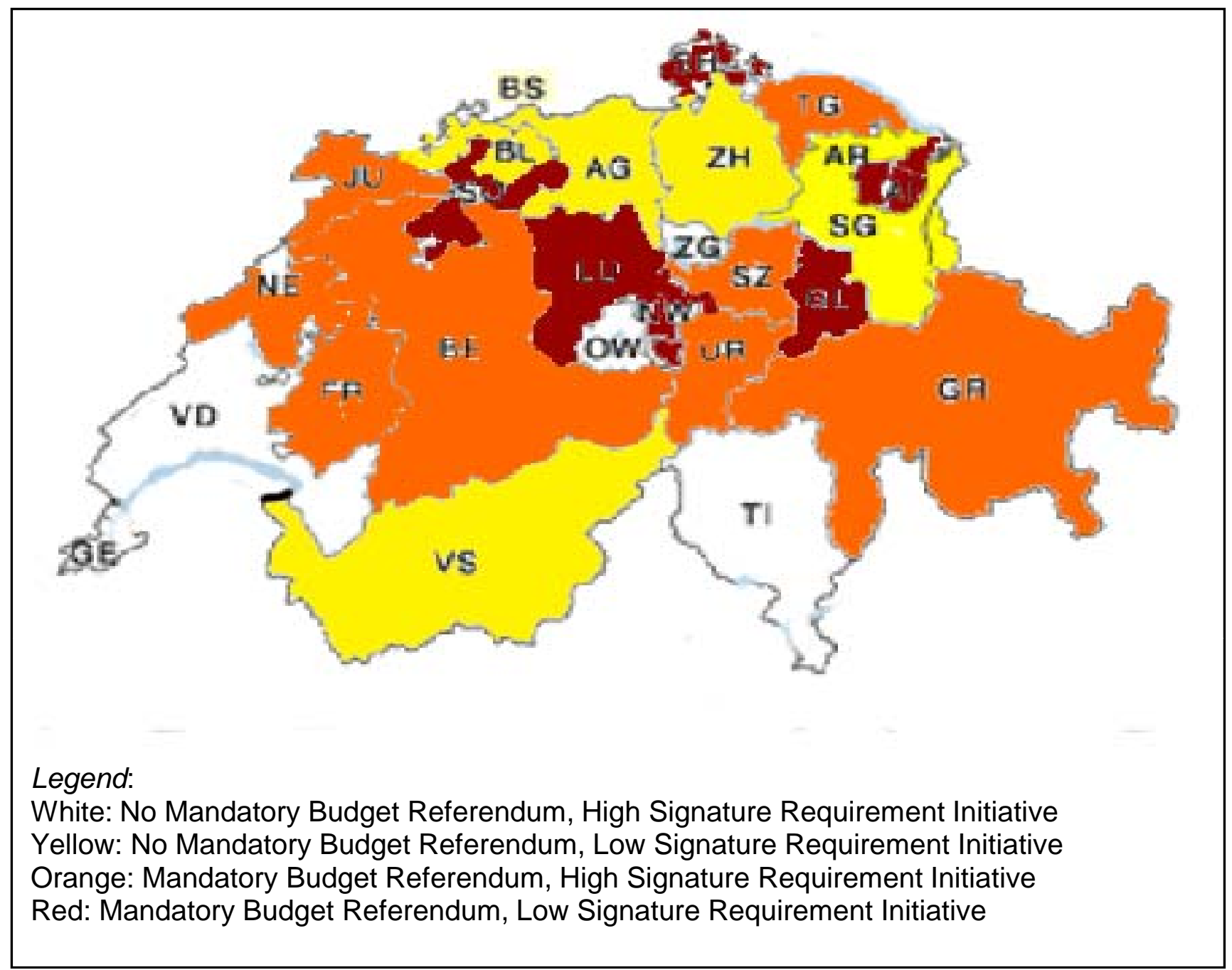


Table A1: Within and Between Canton Variation of Main Variables

\begin{tabular}{|c|c|c|c|c|}
\hline & $\frac{\text { Overall }}{\text { Mean }}$ & $\frac{\text { Total }}{\text { Std. Dev }}$ & $\frac{\text { Between }}{\text { Variation }}$ & $\frac{\text { Within }}{\text { Variation }}$ \\
\hline \multicolumn{5}{|l|}{ Fiscal Policy } \\
\hline Expenditures per capita (log) & 7.16 & 1.26 & 0.35 & 1.22 \\
\hline Revenues per capita (log) & 7.14 & 1.27 & 0.35 & 1.22 \\
\hline Local expenditures in canton (log) & 6.91 & 1.19 & 0.46 & 1.10 \\
\hline Degree of Centralization & 56.48 & 14.78 & 11.74 & 9.34 \\
\hline \multicolumn{5}{|l|}{ Political Institutions } \\
\hline Mandatory budget referendum & 0.65 & 0.48 & 0.38 & 0.30 \\
\hline Signature requirement initiative (\%) & 2.36 & 1.75 & 1.61 & 0.84 \\
\hline Mandatory law referendum & 0.61 & 0.49 & 0.47 & 0.16 \\
\hline Cantonal ballots per year* & 5.63 & 4.08 & 3.01 & 2.82 \\
\hline Size of Parliament & 114.22 & 51.82 & 51.89 & 10.26 \\
\hline Size of Executive & 6.55 & 1.41 & 1.41 & 0.28 \\
\hline Proportional Representation & 0.62 & 0.49 & 0.34 & 0.35 \\
\hline Women Suffrage Adopted? & 0.27 & 0.45 & 0.06 & 0.44 \\
\hline \multicolumn{5}{|l|}{ Control Variables } \\
\hline Age 0 to $19(\%)$ & 33.79 & 6.79 & 3.70 & 5.74 \\
\hline Age 20 to $39(\%)$ & 29.98 & 2.55 & 1.88 & 1.76 \\
\hline Age 40 to $64(\%)$ & 26.79 & 3.47 & 1.75 & 3.01 \\
\hline Age 65 and Above (\%) & 9.44 & 3.56 & 1.15 & 3.38 \\
\hline Log population & 11.64 & 1.10 & 1.09 & 0.27 \\
\hline Urban population (\%) & 25.62 & 25.58 & 24.21 & 9.56 \\
\hline Federal subsidies (log) & 5.43 & 1.21 & 5.16 & 1.07 \\
\hline Labor force participation & 40.67 & 7.66 & 4.14 & 6.49 \\
\hline Employment in primary sector (\%) & 20.28 & 13.89 & 9.52 & 10.29 \\
\hline Employment in secondary sector (\%) & 43.56 & 11.34 & 9.12 & 6.98 \\
\hline Doctors per 1,000 inhabitants & 0.89 & 0.48 & 0.34 & 0.35 \\
\hline Cars owned (\%) & 12.27 & 16.69 & 1.60 & 16.61 \\
\hline Infant mortality rate & 60.28 & 100.45 & 57.81 & 82.95 \\
\hline Linguistic Heterogeneity & 0.20 & 0.21 & 0.16 & 0.14 \\
\hline Religious Heterogeneity & 0.34 & 0.20 & 0.16 & 0.13 \\
\hline
\end{tabular}

Notes: The table reports the overall mean (column (1)) and standard deviation (column (2)) for the variables used in the empirical analysis. Column (3) and column (4) report the variation between and within cantons respectively over our sample period. 
Table A2: Federal Propositions inducing More Federal Spending, 1891-2000

\begin{tabular}{|c|c|c|c|c|c|c|c|c|c|}
\hline Number & Title of Proposition & Year & $\%$ Yes & Outcome & Number & Title of Proposition & Year & $\%$ Yes & Outcome \\
\hline 35 & Disability Insurance for Civil Servants and Public Employees & 1891 & $21 \%$ & No & 302 & Removal of Canton Share in Stamp Duties & 1980 & $67 \%$ & Yes \\
\hline 43 & Share Customs Revenues with Cantons [lessexp] & 1894 & $29 \%$ & No & 303 & Redistribution of Revenues from Alcohol Tax & 1980 & $71 \%$ & Yes \\
\hline 46 & Revision of Military Provisions & 1895 & $42 \%$ & No & 305 & For a new Immigration Policy & 1981 & $16 \%$ & No \\
\hline 52 & Trade with Food (Revise Article 24, Constitution) & 1897 & $65 \%$ & Yes & 308 & Improving Federal Finances & 1981 & $69 \%$ & Yes \\
\hline 53 & Nationalisation of Swiss Railways & 1898 & $68 \%$ & Yes & 312 & Regulation of Gas Taxes & 1983 & $53 \%$ & Yes \\
\hline 56 & Health and Accident Insurance & 1900 & $30 \%$ & No & 313 & Energy Article & 1983 & $49 \%$ & No \\
\hline 60 & Revision of Tariffs on Foreign Products [lessexp] & 1903 & $60 \%$ & Yes & 316 & Introduction of User Fee for Heavy Traffic & 1984 & $59 \%$ & Yes \\
\hline 66 & Change in Organization of Swiss Military & 1907 & $55 \%$ & Yes & 317 & User Fee for Highways (Nationalstrassen) & 1984 & $53 \%$ & Yes \\
\hline 71 & Health and Accident Insurance & 1912 & $54 \%$ & Yes & 323 & Protection Motherhood & 1984 & $15 \%$ & No \\
\hline 99 & Initiative for Old Age, Widow and Disability Insurance & 1925 & $42 \%$ & Yes & 324 & Regulation of Radio and Television & 1984 & $69 \%$ & Yes \\
\hline 101 & Federal Law on Old Age, Widow and Disability Insurance & 1925 & $65 \%$ & Yes & 331 & Removal of Canton Share in Stamp Duties & 1985 & $67 \%$ & Yes \\
\hline 102 & Constitutional Amendment Regarding Corn Supply & 1926 & $50 \%$ & No & 332 & Redistribution of Revenues from Alcohol Tax & 1985 & $72 \%$ & Yes \\
\hline 115 & Old Age and Widow Insurance & 1931 & $40 \%$ & No & 335 & Subsidies for Small and Medium-Sized Firms & 1985 & $43 \%$ & No \\
\hline 117 & Temporary Decrease in Salaries of Public Employees & 1933 & $45 \%$ & No & 339 & Culture Initiative & 1986 & $43 \%$ & No \\
\hline 119 & Change in Organization of Military Training & 1935 & $54 \%$ & Yes & 340 & Secure Vocational Training and Retraining & 1986 & $17 \%$ & No \\
\hline 121 & Fight Economic Crisis & 1935 & $43 \%$ & No & 341 & Domestic Sugar Industry Regulation & 1986 & $38 \%$ & No \\
\hline 131 & Loans for Military Investment and Reduce Unemployment & 1939 & $69 \%$ & Yes & 342 & Protection of Renters & 1986 & $63 \%$ & Yes \\
\hline 132 & Change in Insurance for Civil Servants & 1939 & $44 \%$ & No & 348 & Railway 2000 & 1987 & $56 \%$ & Yes \\
\hline 139 & Protecting the Family & 1945 & $76 \%$ & Yes & 349 & Protection of the Moor & 1987 & $57 \%$ & Yes \\
\hline 141 & Establishing a Right of Holding a Job & 1946 & $19 \%$ & No & 350 & Reform Health Insurance & 1987 & $28 \%$ & No \\
\hline 142 & Economic Reforms and Right of Holding a Job & 1947 & $31 \%$ & No & 351 & Constitutional Basis for Transport Policy & 1988 & $46 \%$ & No \\
\hline 143 & Revision of Economic Laws in the Constitution & 1947 & $53 \%$ & Yes & 352 & Decrease Retirement Age & 1988 & $35 \%$ & No \\
\hline 145 & Regulation of Swiss Sugar Industry & 1948 & $36 \%$ & No & 363 & Regulation of Wine Industry & 1990 & $46 \%$ & No \\
\hline 150 & Subsidies for Housing Construction & 1950 & $46 \%$ & No & 367 & Energy Supply Article & 1990 & $71 \%$ & Yes \\
\hline 157 & Contribution to Costs of National Defense & 1951 & $33 \%$ & No & 368 & Change in Traffic Law & 1990 & $52 \%$ & Yes \\
\hline 159 & Subsidies for Agriculture & 1952 & $64 \%$ & Yes & 370 & Promoting Public Transport & 1991 & $37 \%$ & No \\
\hline 168 & Changes in Federal Finances & 1953 & $42 \%$ & No & 371 & Reform of Federal Finances & 1991 & $46 \%$ & No \\
\hline 171 & Subsidies for Swiss War Veterans Living Abroad & 1954 & $44 \%$ & No & 373 & Financing of Health Insurance & 1992 & $39 \%$ & No \\
\hline 177 & Subsidy for Canton Grisons & 1956 & $43 \%$ & No & 377 & Protection of Waters & 1992 & $66 \%$ & Yes \\
\hline 178 & Changes in Order for Wheat Production & 1956 & $39 \%$ & No & 381 & Saving the Waters & 1992 & $37 \%$ & No \\
\hline 187 & Improving the Road Infrastructure & 1958 & $85 \%$ & Yes & 382 & Building Railway through the Alps & 1992 & $63 \%$ & Yes \\
\hline 194 & Subsidies for Milk Producers & 1960 & $56 \%$ & Yes & 386 & Raise Salary of Parliamentary Members & 1992 & $27 \%$ & No \\
\hline 196 & Gas Tax for Financing Highway Construction (Nationalstrasser & 1961 & $47 \%$ & No & 387 & Improve Infrastructure for Parliamentary Members & 1992 & $30 \%$ & No \\
\hline 201 & Salaries of Representatives and Government Members & 1962 & $32 \%$ & No & 389 & Increase in Gas Tax & 1993 & $55 \%$ & Yes \\
\hline 205 & Scholarships and Other Training Subsidies & 1963 & $79 \%$ & Yes & 398 & Unemployment Insurance & 1993 & $70 \%$ & Yes \\
\hline 207 & Vocational Training & 1964 & $67 \%$ & Yes & 399 & Federal Finances & 1993 & $67 \%$ & Yes \\
\hline 219 & Subsidies for Domestic Sugar Industry & 1970 & $54 \%$ & Yes & 400 & Improving Federal Finances & 1993 & $58 \%$ & Yes \\
\hline 222 & Housing Guarantee and Protection of Families & 1970 & $49 \%$ & No & 401 & Maintenance of Social Security & 1993 & $63 \%$ & Yes \\
\hline 223 & Changes in Federal Finances & 1970 & $55 \%$ & No & 405 & Continuing Highway Fee & 1994 & $69 \%$ & Yes \\
\hline 227 & Subsidies for Apartment Construction & 1972 & $30 \%$ & No & 406 & Continuing Heavy Traffic Fee & 1994 & $72 \%$ & Yes \\
\hline 232 & Changes in Old Age and Disability Insurance & 1972 & $16 \%$ & No & 407 & Introduction of User Fee for Heavy Traffic & 1994 & $67 \%$ & Yes \\
\hline 235 & Subsidies for Scientific Research & 1973 & $65 \%$ & Yes & 410 & Promote Culture & 1994 & $50 \%$ & No \\
\hline 240 & Restriction on Deductions of Income Tax & 1973 & $68 \%$ & Yes & 415 & Change in Health Insurance & 1994 & $51 \%$ & Yes \\
\hline 245 & Socially Acceptable Health Insurance & 1974 & $27 \%$ & No & 416 & For a new Health Insurance & 1994 & $23 \%$ & No \\
\hline 248 & Financing Highway Construction (Nationalstrassen) & 1975 & $54 \%$ & Yes & 423 & Securing Invalidity/Age Insurance & 1995 & $27 \%$ & No \\
\hline 249 & Changes in General Customs Tariffs & 1975 & $48 \%$ & No & 430 & For an Environmentally Oriented Agriculture & 1996 & $77 \%$ & Yes \\
\hline 258 & Loan to International Development Agency & 1976 & $44 \%$ & No & 431 & Re-Organisation Administration & 1996 & $39 \%$ & No \\
\hline 268 & Changes in Sales Tax and Direct Federal Tax & 1977 & $41 \%$ & No & 442 & Introduction of User Fee for Heavy Traffic & 1998 & $57 \%$ & Yes \\
\hline 281 & Decrease Retirement Age & 1978 & $21 \%$ & No & 444 & Reform of Age Insurance & 1998 & $41 \%$ & No \\
\hline 286 & Subsidies for Universities/Technical Colleges & 1978 & $43 \%$ & No & 445 & Infrastructure for Public Transportation & 1998 & $63 \%$ & Yes \\
\hline 289 & Milk Production & 1978 & $69 \%$ & Yes & 458 & Law on Insurance of Motherhood & 1999 & $38 \%$ & No \\
\hline 291 & Federal Responsibility for Security & 1978 & $44 \%$ & No & 465 & Subsidies for Solar Energy (Solarrappen) & 2000 & $31 \%$ & No \\
\hline 294 & Subsidize Hiking Trails & 1979 & $76 \%$ & Yes & 469 & For a flexible Age Insurance & 2000 & $39 \%$ & No \\
\hline 297 & Changes in Sales Tax and Direct Federal Tax & 1979 & $35 \%$ & No & 470 & For a flexible Retirement Age & 2000 & $46 \%$ & No \\
\hline
\end{tabular}

Notes: The table lists the federal propositions, which would have increased the size of government through higher spending, taxes or subsidies. The financial consequences of a proposition were assessed using the official documents by the federal government (available at http://Www.ads.bar.admin.ch/ADS/showHome.do), which are distributed to each citizen before the vote. The
reports the final outcome. For vote \#223, the majority of the electorate voted in favor but the Council of States rejected it. 
Table A3: Additional Results

\begin{tabular}{|c|c|c|c|c|}
\hline & $\begin{array}{c}\frac{\text { Absolute \# }}{\text { of Signatures }} \\
\frac{\text { Law Initiative }}{(1)}\end{array}$ & $\frac{\frac{\text { Discrete }}{\text { Signature }}}{\text { Requirement }}$ & $\begin{array}{c}\frac{\text { Interaction }}{\text { Budget Ref. }} \\
\frac{\text { Law Initiative }}{(3)}\end{array}$ & $\begin{array}{c}\text { Effect by } \\
\text { Subperiods } \\
(4)\end{array}$ \\
\hline \multicolumn{5}{|l|}{ Y: Canton Expenditures } \\
\hline$\overline{\text { Budget Referendum }}$ & $\begin{array}{c}-0.034 \\
(0.014)^{\star \star}\end{array}$ & $\begin{array}{c}-0.036 \\
(0.014)^{\star \star \star}\end{array}$ & $\begin{array}{c}0.012 \\
(0.016)\end{array}$ & $\begin{array}{c}-0.048 \\
(0.017)^{\star \star \star}\end{array}$ \\
\hline Signature Requirement Initiative (\%) & & & $\begin{array}{c}0.008 \\
(0.002)^{\star \star \star}\end{array}$ & $\begin{array}{c}0.022 \\
(0.005)^{\star \star \star}\end{array}$ \\
\hline \# Signatures Required Initiative/100 & $\begin{array}{c}0.001 \\
(0.0004)^{\star \star \star}\end{array}$ & & & \\
\hline Signature Requirement $1 \%$ or less & & $\begin{array}{c}-0.324 \\
(0.043)^{\star \star \star}\end{array}$ & & \\
\hline Signature Requirement 1 to $3 \%$ & & $\begin{array}{c}-0.175 \\
(0.039)^{\star \star \star}\end{array}$ & & \\
\hline Signature Requirement More than 3\% & & $\begin{array}{c}-0.099 \\
(0.035)^{\star \star \star}\end{array}$ & & \\
\hline Interaction Effect BRef*Initiative & & & $\begin{array}{c}-0.016 \\
(0.003)^{\star \star \star}\end{array}$ & \\
\hline Budget Referendum before 1945 & & & & $\begin{array}{c}0.014 \\
(0.019)\end{array}$ \\
\hline Signature Requirement before 1945 & & & & $\begin{array}{c}-0.017 \\
(0.005)^{\star \star \star}\end{array}$ \\
\hline Year Fixed Effects & Yes & Yes & Yes & Yes \\
\hline Canton Fixed Effects & Yes & Yes & Yes & Yes \\
\hline Canton Characteristics & Yes & Yes & Yes & Yes \\
\hline Observations & 2524 & 2524 & 2524 & 2524 \\
\hline R Squared & 0.98 & 0.98 & 0.98 & 0.98 \\
\hline \multicolumn{5}{|l|}{ Y: Local Expenditures } \\
\hline$\overline{\text { Budget Referendum }}$ & $\begin{array}{c}-0.058 \\
(0.027)^{\star \star}\end{array}$ & $\begin{array}{l}-0.026 \\
(0.024)\end{array}$ & $\begin{array}{c}0.183 \\
(0.028)^{\star \star \star}\end{array}$ & $\begin{array}{l}-0.026 \\
(0.029)\end{array}$ \\
\hline Signature Requirement Initiative & & & $\begin{array}{c}0.030 \\
(0.003)^{\star \star \star}\end{array}$ & $\begin{array}{l}0.011 \\
(0.010)\end{array}$ \\
\hline \# Signatures Required Initiative/100 & $\begin{array}{c}0.0003 \\
(0.0007)\end{array}$ & & & \\
\hline Signature Requirement $1 \%$ or less & & $\begin{array}{c}-0.363 \\
(0.079)^{\star \star \star}\end{array}$ & & \\
\hline Signature Requirement 1 to $3 \%$ & & $\begin{array}{c}-0.412 \\
(0.071)^{\star \star \star}\end{array}$ & & \\
\hline Signature Requirement More than $3 \%$ & & $\begin{array}{c}-0.445 \\
(0.064)^{\star \star \star}\end{array}$ & & \\
\hline Interaction Effect BRef*Initiative & & & $\begin{array}{c}-0.069 \\
(0.005)^{\star \star \star}\end{array}$ & \\
\hline Budget Referendum before 1945 & & & & $\begin{array}{c}0.008 \\
(0.035)\end{array}$ \\
\hline Signature Requirement before 1945 & & & & $\begin{array}{c}0.006 \\
(0.009)\end{array}$ \\
\hline Year Fixed Effects & Yes & Yes & Yes & Yes \\
\hline Canton Fixed Effects & Yes & Yes & Yes & Yes \\
\hline Canton Characteristics & Yes & Yes & Yes & Yes \\
\hline Observations & 2490 & 2410 & 2410 & 2410 \\
\hline R Squared & 0.93 & 0.93 & 0.93 & 0.93 \\
\hline
\end{tabular}

Notes: The table reports results for log canton expenditures (top panel) and log local expenditures (bottom panel). Column (1) uses a discrete measure for the signature requirement with the omitted group of no voter initiative. Column (2) uses the absolute number of signatures for the law initiative (divided by 1000). Column (3) includes the interaction between mandatory budget referendum and the signature requirement for the law initiative. Column (4) allows the coefficients for the direct democratic institutions to vary before and after the end of World War II in 1945. ${ }^{\star} p<0.01,{ }^{\star \star} p<0.05$ and ${ }^{\star \star *} p<0.01$. Robust standard errors are reported in parentheses. 
Table A4: Dynamic Effects of Direct Democracy on Government Spending

\begin{tabular}{|c|c|c|c|c|c|c|}
\hline log Canton Expenditures & $\begin{array}{c}4-6 \text { Years } \\
\text { before Change } \\
(1) \\
\end{array}$ & $\begin{array}{c}1-3 \text { Years } \\
\text { before Change } \\
(2) \\
\end{array}$ & $\begin{array}{c}0-4 \text { Years } \\
\text { after Change } \\
\text { (3) } \\
\end{array}$ & $\begin{array}{c}\text { More than } 5 \text { Years } \\
\text { after Change } \\
(4)\end{array}$ & $\begin{array}{c}p \text { value } \\
4-6 \text { vs } 1-3 \text { yrs. } \\
(6) \\
\end{array}$ & $\begin{array}{c}p \text { value } \\
0-4 \text { vs } 5+y r s . \\
(7) \\
\end{array}$ \\
\hline Adopt Budget Referendum & $\begin{array}{c}-0.064 \\
(0.023)^{\star \star \star}\end{array}$ & $\begin{array}{c}0.081 \\
(0.028)^{\star \star \star}\end{array}$ & $\begin{array}{c}0.049 \\
(0.025)^{\star}\end{array}$ & $\begin{array}{c}0.005 \\
(0.017)\end{array}$ & 0.00 & 0.01 \\
\hline Abolish Budget Referendum & $\begin{array}{c}0.001 \\
(0.015)\end{array}$ & $\begin{array}{c}0.04 \\
(0.020)^{\star \star}\end{array}$ & $\begin{array}{c}0.076 \\
(0.025)^{\star \star \star}\end{array}$ & $\begin{array}{c}0.167 \\
(0.026)^{\star \star \star}\end{array}$ & 0.20 & 0.01 \\
\hline Change Signatures Law Initiative & $\begin{array}{c}0.03 \\
(0.016)^{*}\end{array}$ & $\begin{array}{l}-0.008 \\
(0.020)\end{array}$ & $\begin{array}{c}0.035 \\
(0.016)^{\star \star}\end{array}$ & $\begin{array}{c}0.271 \\
(0.030)^{\star \star \star}\end{array}$ & 0.25 & 0.00 \\
\hline
\end{tabular}

Notes: The table reports estimates and standard errors (in parentheses) for dummy variables denoting time periods relative to changes in direct democratic institutions. The dependent variable is the log of canton expenditures. All specifications control for state and year fixed effects and the same canton characteristics as in column ( 3 ) of Table 3. The $p$-values correspond to the F-statistics are shown in the last three columns) ${ }^{\star} p<0.10,{ }^{\star \star} p<0.05,{ }^{\star \star *} p<0.01$. Robust standard errors in parentheses. 
Table A5: Feedback Effects between Spending and Changes in Direct Democracy

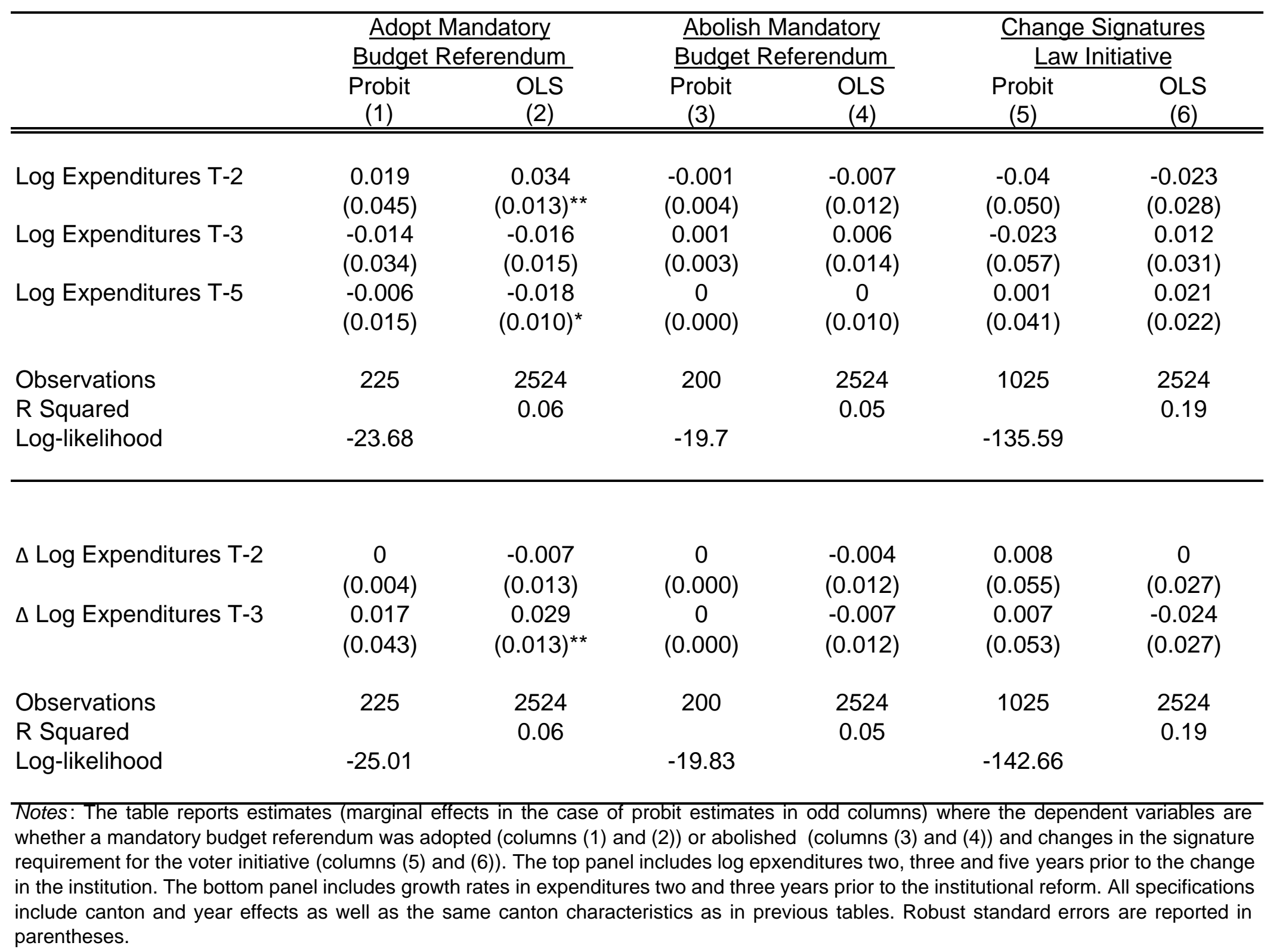

